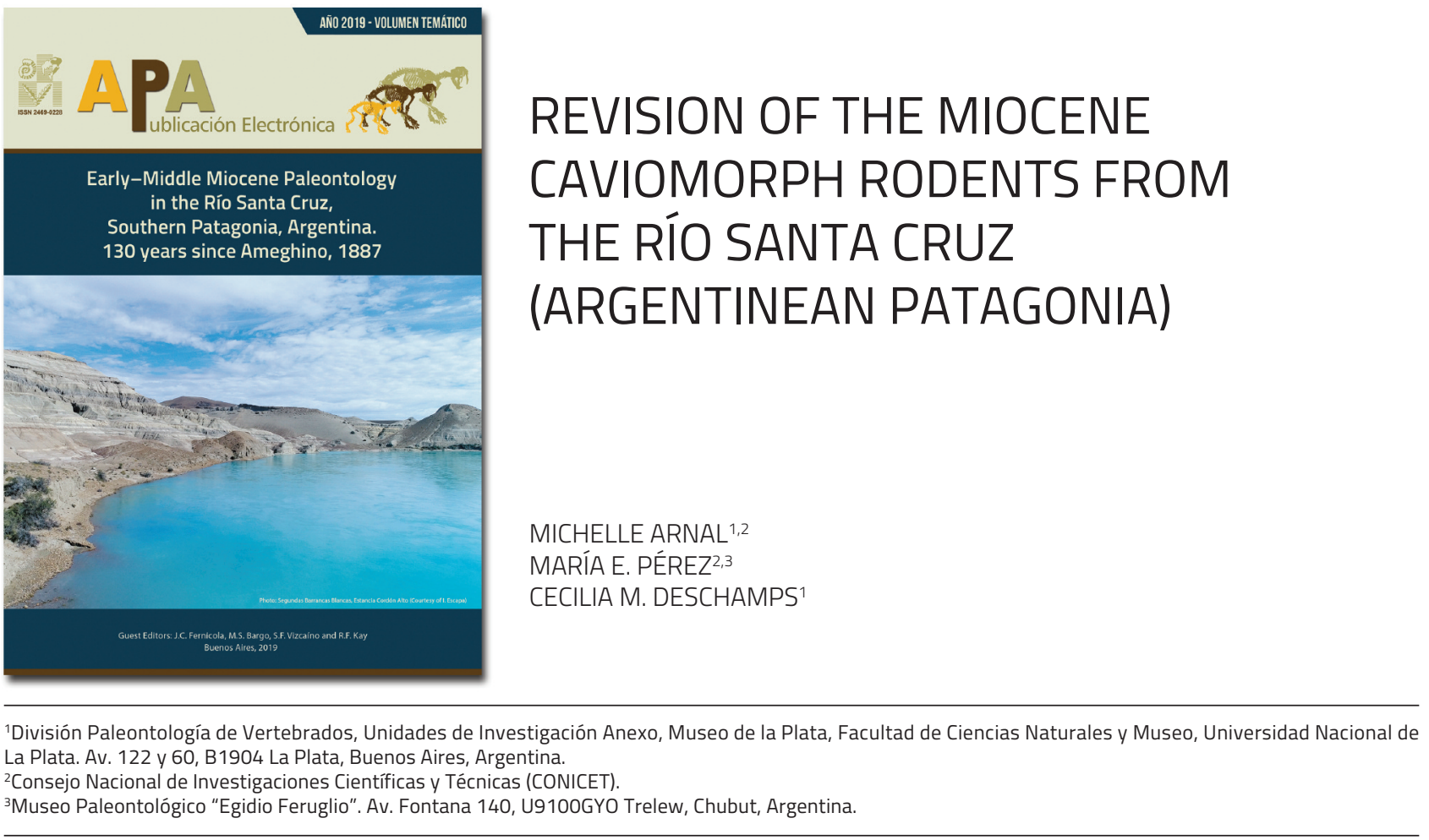

Recibido: 22 de mayo 2019 - Aceptado: 25 de septiembre 2019

Para citar este artículo: Michelle Arnal, María E. Pérez, and Cecilia M. Deschamps (2019). Revision of the Miocene caviomorph rodents from the Río Santa Cruz (Argentinean Patagonia). Publicación Electrónica de la Asociación Paleontológica Argentina 19 (2): 193-229.

Link a este artículo: http://dx.doi.org/10.5710/PEAPA.25.09.2019.299

DESPLAZARSE HACIA ABAJO PARA ACCEDER AL ARTíCULO

Asociación Paleontológica Argentina Maipú $6451^{\circ}$ piso, C1006ACG, Buenos Aires

República Argentina

Tel/Fax (54-11) 4326-7563

Otros artículos en Publicación Electrónica de la APA 19(2): Web: www.apaleontologica.org.ar

\section{J. Diederle, J. Noriega}

NEW RECORDS OF BIRDS IN THE SANTA CRUZ FORMATION AT RÍO SANTA CRUZ, ARGENTINA, PATAGONIA

\section{J.C. Fernicola, S.F. Vizcaíno}

CINGULATES (MAMMALIA, XENARTHRA) OF THE SANTA CRUZ FORMATION (EARLY-MIDDLE MIOCENE, BURDIGALIAN) FROM THE RÍO SANTA CRUZ, ARGENTINE PATAGONIA

\section{J.C. Fernicola et al.}

ANALYSIS OF THE EARLY-MIDDLE MIOCENE MAMMAL ASSOCIATIONS AT THE RÍO SANTA CRUZ (PATAGONIA, ARGENTINA) 


\title{
REVISION OF THE MIOCENE CAVIOMORPH RODENTS FROM THE RÍO SANTA CRUZ (ARGENTINEAN PATAGONIA)
}

\author{
MICHELLE ARNAL 1,2, MARÍA E. PÉREZ2,3, AND CECILIA M. DESCHAMPS¹
}

12División Paleontología de Vertebrados, Unidades de Investigación Anexo, Museo de la Plata, Facultad de Ciencias Naturales y Museo, Universidad Nacional de La Plata. Av. 122 y 60, B1904 La Plata, Buenos Aires, Argentina. michoarnal@fcnym.unlp.edu.ar, ceci@fcnym.unlp.edu.ar

${ }^{2}$ Consejo Nacional de Investigaciones Científicas y Técnicas (CONICET).

${ }^{3}$ Museo Paleontológico "Egidio Feruglio". Av. Fontana 140, U9100GYO Trelew, Chubut, Argentina. mperez@mef.org.ar

Abstract. Fossil rodents from the Río Santa Cruz (RSC) classic localities (Santa Cruz Formation, Early-Middle Miocene) are known by the works of F. Ameghino and W.B. Scott since the end of the $19^{\text {th }}$ and beginning of the $20^{\text {th }}$ centuries. These caviomorph rodents have not been comprehensively reviewed since then. In this contribution, we studied new fossil specimens from the cliffs of the RSC (Province of Santa Cruz, Argentina) collected with accurate stratigraphic and geographic data during fieldtrips in 2013 and 2014. An increase in the caviomorph taxonomic richness is observed, based upon our taxonomic study of caviomorphs previously recorded in the RSC. Also, these fieldworks recovered for the first time several taxa previously found in other Santacrucian and even older Patagonian localities (Colhuehuapian, Early Miocene). As a general evolutionary pattern, we note an increase of derived euhypsodont taxa (Prolagostomus, Pliolagostomus, Schistomys, and Eocardia) in Segundas Barrancas Blancas (16.47-15.3 Ma). In addition, a taxonomic replacement of Phanomys by Schistomys is noted between Barrancas Blancas (17.21-16.3 Ma) and Segundas Barrancas Blancas, as well as a notably increase in the abundance of the large Perimys onustus in the latter locality. The present study provides a revision of the caviomorph systematics, and intends to be the starting point to understand the diversity (in all its aspects) and the evolution of this group during the Santacrucian, a major event in the South American mammalian history.

Key words. Santacrucian. Province of Santa Cruz. Hystricognathi. Taxonomy. Systematics. Biostratigraphy. Evolution.

Resumen. REVISIÓN DE LOS ROEDORES CAVIOMORFOS MIOCENOS DEL RÍO SANTA CRUZ (PATAGONIA ARGENTINA). Los roedores fósiles provenientes de localidades del Río Santa Cruz (RSC; Formación Santa Cruz, Mioceno Temprano-Medio) se conocen desde fines del siglo 19 y principios del 20, gracias a los trabajos de F. Ameghino y W.B. Scott. Sin embargo, no fueron estudiados a nivel integral desde ese momento. En este sentido, analizamos nuevos ejemplares recolectados en las barrancas del RSC (Santa Cruz, Argentina) durante los años 2013 y 2014 que cuentan con datos de procedencia estratigráfica y geográfica precisos. El estudio taxonómico permitió reconocer taxones previamente descriptos para el RSC, así como nuevos taxones conocidos en otras localidades santacrucenses o en localidades más antiguas de Patagonia (Colhuehuapense, Mioceno Temprano). Se corroboró un aumento en la riqueza taxonómica del conjunto de roedores del RSC. Como patrón evolutivo general, se observa un incremento de formas euhipsodontes derivadas (Prolagostomus, Pliolagostomus, Schistomys, Eocardia) en Segundas Barrancas Blancas (16,47-15,3 Ma). A su vez, observamos un reemplazo taxonómico de Phanomys por Schistomys desde la localidad de Barrancas Blancas (17,21-16,3 Ma) a Segundas Barrancas Blancas y un notable aumento en la abundancia de Perimys onustus, la especie más grande del género, en esta última localidad. El presente estudio es una puesta al día de la sistemática de los caviomorfos del RSC y pretende ser el punto de partida para entender la diversidad y la evolución de los caviomorfos durante el Santacrucense, un periodo crucial en la historia de los mamíferos sudamericanos.

Palabras clave. Santacrucense. Provincia de Santa Cruz. Hystricognathi. Taxonomía. Sistemática. Bioestratigrafía. Evolución.

CAVIOMORPHS are the endemic hystricognath rodents of Central and South America (Wood, 1955; Upham and Patterson, 2015). They constitute the most diverse group of rodents from a morphological and ecological point of view, and have a long evolutionary history during the Cenozoic (Vassallo and Antenucci, 2015; Vucetich et al., 2015). The systematics and biology of extant taxa have been intensively studied and are relatively well-known (Álvarez et al., 2011; Patton et al., 2015; Vassallo and Antenucci, 2015). However, these aspects still require intensive study in fossils. In this regard, the Early Miocene represents a crucial moment in the evolutionary history of caviomorphs since the fossil record indicates that Santacrucian rodents were a critical part of an important caviomorph diversification (Pérez and Pol, 2012; 
Arnal and Vucetich, 2015a; but see Verzi et al., 2014). The Early-Middle Miocene of Patagonia (Colhuehuapian, "Pinturan", Santacrucian, and "Colloncuran" South American Land Mammal Ages, SALMA), has yielded an excellent record of mammals (e.g., Ameghino, 1887a,b, 1889; Scott, 1905; Kramarz, 2001, 2002, 2004, 2006a,b; Kramarz et al., 2010, 2013; Pérez, 2010a; Pérez et al., 2010; Vucetich et al., 2010; Pérez and Vucetich, 2012; Vizcaíno et al., 2012a; Arnal and Pérez, 2013; González Ruiz et al., 2013, 2017; Brandoni et al., 2017, 2019; Vera et al., 2017, 2018; Busker et al., 2018; Rasia and Candela, 2019). In particular, the Santa Cruz Formation (Early-Middle Miocene; Santacrucian) is widely distributed in the Province of Santa Cruz, Argentina (Fig. 1; Cuitiño et al., 2016, 2019). It is one of the richest Cenozoic vertebrate fossil units bearing abundant and well-preserved specimens. Caviomorphs recorded in the cliffs of the classic localities of the Río Santa Cruz (RSC; Fig. 1) were first studied by F. Ameghino (1887a,b, 1889, 1891a,b, 1894) who erected 23 caviomorph genera and 45 species (Tab. 1). These rodents were later revised by Scott (1905) who described new species from other Santacrucian localities of the Province of Santa Cruz (Fig. 1), but no new caviomorph genera were identified. In this regard, Scott (1905, p. 384) stated: "It must not be supposed that the full number of Santa Cruz genera has been already discovered, though it is improbable that the list will be very greatly extended in the future". Since that time, several other Santacrucian-age localities have been identified at high and middle latitudes of South America. However, caviomorphs have been listed or mentioned in only some of them: coastal localities in the Province of Santa Cruz (Tauber, 1997; Candela et al., 2012), Las Hornillas, Province of San Juan, Argentina (López et al., 2011), Alto Río Cisnes (Marshall and Salinas, 1990), Pampa Castillo (Flynn et al., 2002), Laguna del Laja (Flynn et al., 2008), and Sierra Baguales (Bostelmann et al., 2013) of southern Chile, and Chucal of northern Chile (Croft et al., 2004). In agreement with Scott's conclusion, almost no new taxa were formally recognized since Ameghino's work (but see Arnal and Vucetich, 2015b).

Santacrucian rodents are very abundant in number of specimens but relatively homogeneous in their morphological disparity (Scott, 1905; Vucetich et al., 2015). When compared with rodents from the lower and middle sequences of the Pinturas and Sarmiento formations ("Pinturan" and Colhuehuapian SALMAS, Early Miocene), those from beds of the Santa Cruz Formation show some differences. Santacrucian octodontoids are characteristically more hypsodont and more lophate than their predecessors; euhypsodont cavioids predominate for the first time; erethizontoids are less abundant and less diverse, and chinchilloids reach their greatest diversity (Vucetich et al., 2015, and literature therein). The dental changes toward increasing hypsodonty and trend towards more simplified occlusal surfaces were traditionally related to the environmental and climatic changes that occurred since the Late Eocene-Early Oligocene, which were more marked in Patagonia at that time (Pascual et al., 1996; Zachos, 2001; Ortiz Jaureguizar and Cladera, 2006; Madden, 2015; Vizcaíno et al., 2012a).

Despite the importance of this rodent fauna owing to their excellent fossil record and widespread geographical distribution, no comprehensive studies of the caviomorph assemblages either from the RSC or from other Santacrucian localities have been performed to date. Only partial revisions or isolated studies of specimens from different Santacrucian localities have been published (Pérez, 2010b; Arnal, 2012; Pérez and Vucetich, 2012; Arnal and Vucetich, 2015b; Arnal et al., 2017).

A particular problem of this fauna is that the abundant fossil remains found by Carlos Ameghino in the RSC and other localities lack accurate geographic and stratigraphic data, which makes comparisons between localities and biostratigraphic correlations difficult (Fernicola et al., 2019). Since those first collections, almost no new intensive field work had been made to remedy this deficiency. At the beginning of the $21^{\text {th }}$ century a group of scientists headed by Drs. S.F. Vizcaíno, M.S. Bargo (Museo de La Plata, MLP), R.F. Kay (Duke University, USA), and J.C. Fernicola (Museo Argentino de Ciencias Naturales "Bernardino Rivadavia"), launched a project focused on the Santa Cruz rocks (Santa Cruz Formation, Early-Middle Miocene) cropping out along the Atlantic coast of the Province of Santa Cruz, and along the cliffs on the southern bank of the RSC. Within this project, numerous new specimens with good stratigraphic provenance were collected (Vizcaíno et al., 2012a; Fernicola et al., 2014, 2019; Cuitiño et al., 2016), which considerably 


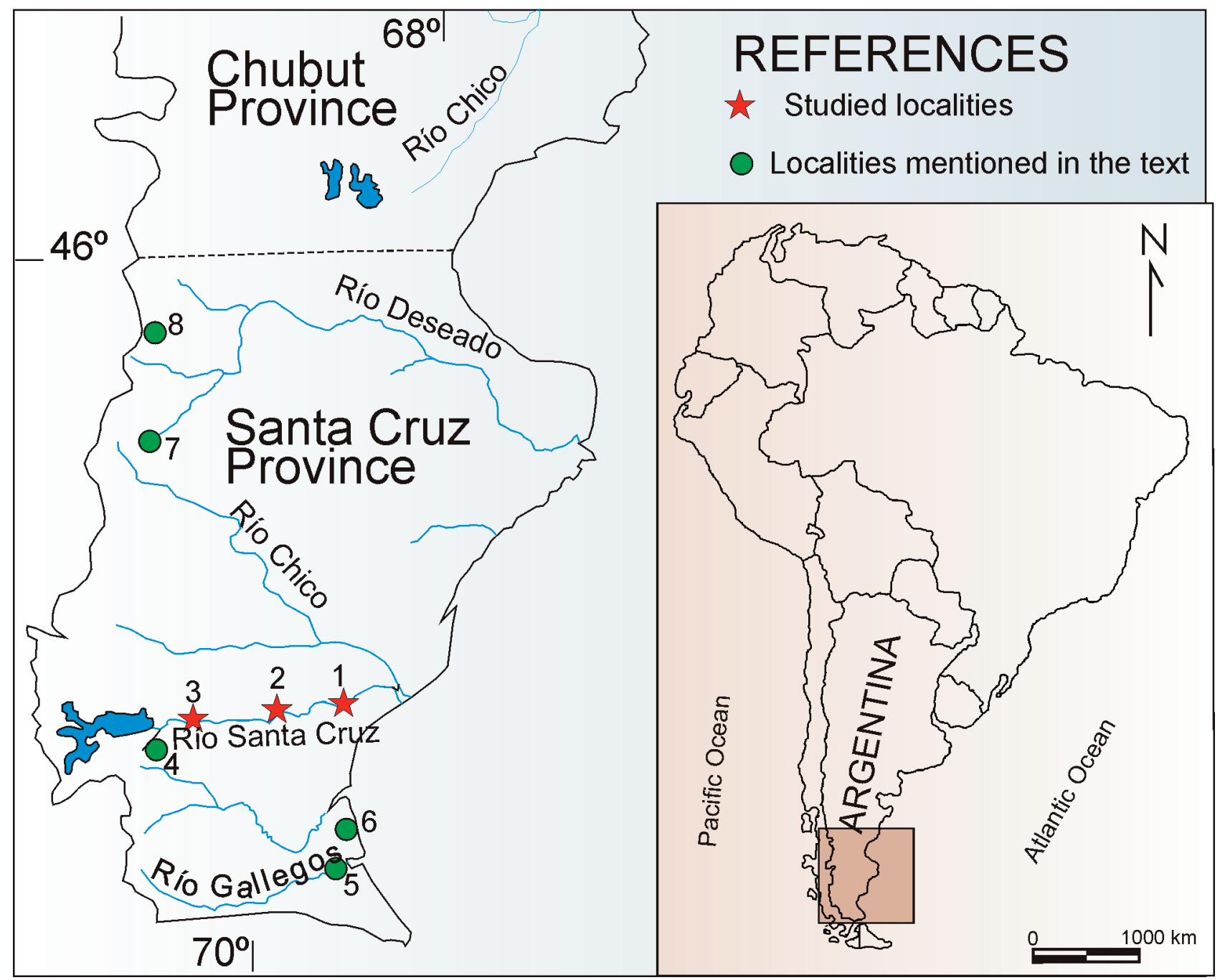

Figure 1. Location map showing the Santacrucian and other localities mentioned in the text. 1, Barrancas Blancas (BB); 2, Segundas Barrancas Blancas (SBB); 3, Yaten Huageno (YH); 4, Río Bote; 5, Killik Aike; 6, Guer Aike; 7, río Pinturas area; 8, río Jeinemeni area.

enlarge the Santacrucian caviomorph collections and allow integral studies of the whole Santacrucian assemblage to be performed. Furthermore, on the basis of a systematic revision and owing to the precise provenance data, different Santacrucian localities bearing rodents can now be harnessed in the search for evolutionary trends related to climatic and environmental changes. In this contribution, a revision of the caviomorph rodents from the Santa Cruz Formation at the RSC is performed, including new specimens. Their taxonomic richness is compared with those from other Santacrucian localities of the Province of Santa Cruz (Scott, 1905; Candela et al., 2012; Fernicola et al., 2019). Additionally, general evolutionary trends of the group are also discussed.

\section{MATERIALS AND METHODS}

More than 750 fossil specimens (Appendix 1) housed at the Vertebrate Paleontology Collection of the Museo Regional Provincial "Padre Manuel Jesús Molina" (MPM-PV) were studied. Several Santacrucian caviomorphs specimens were used for comparison, mainly those housed at the American Museum of Natural History (AMNH), New York, USA; Field Museum of Natural History (FMNH), Chicago, USA; Museo Argentino de Ciencias Naturales "Bernardino Rivadavia", Ameghino National Collection (MACN-A), Buenos Aires, Argentina; Museo de La Plata, La Plata, Argentina (MLP); Museum National d'Histoire Naturelle (MNHN), Paris, France; Museo Paleontológico Egidio Feruglio (MPEF-PV), 
TABLE 1 - Caviomorph rodents from the Río Santa Cruz described by Ameghino

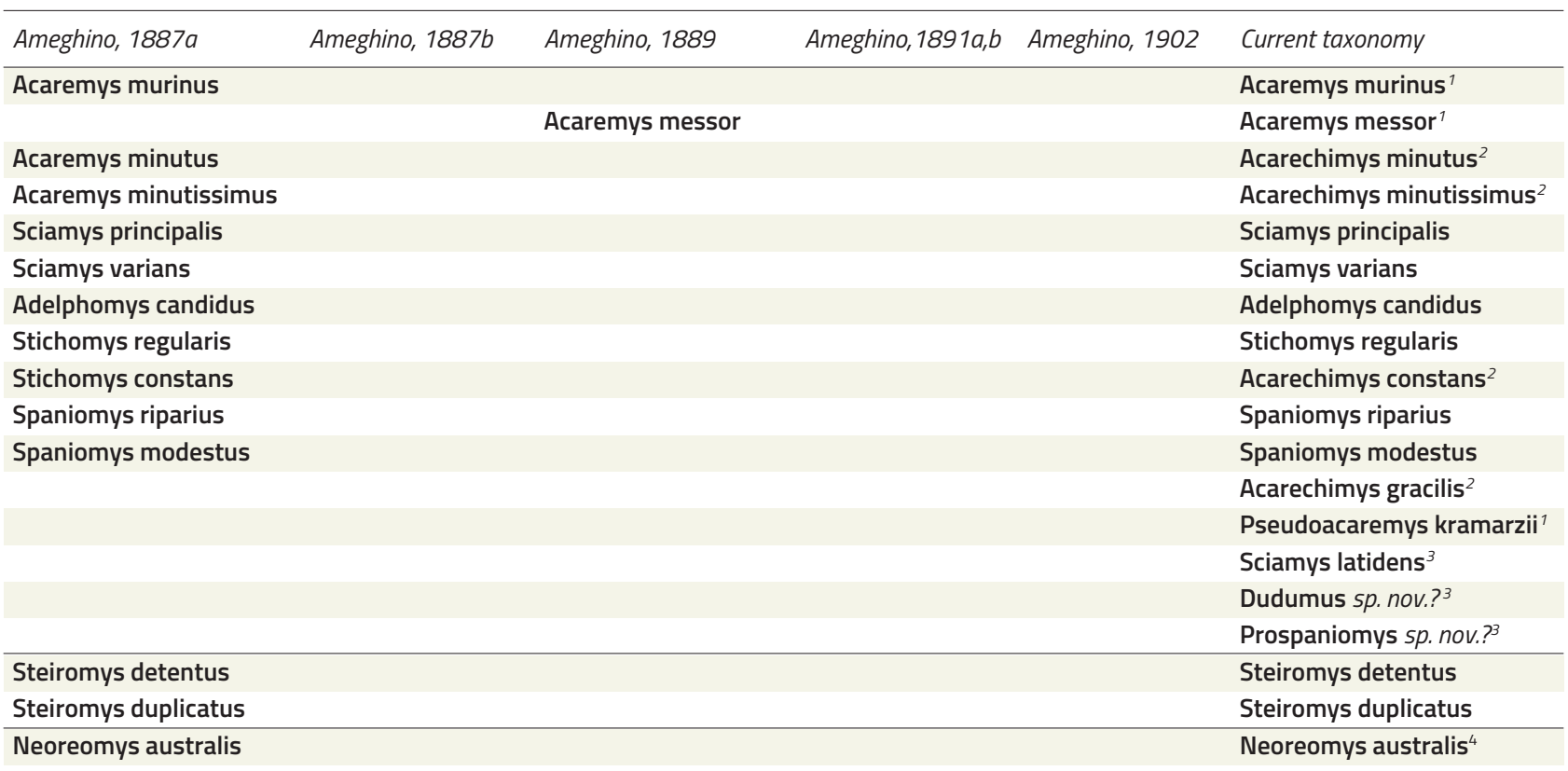

Neoreomys indivisus

Neoreomys decisus

Eocardia montana

Eocardia divisa

Neoreomys insulatus ${ }^{4}$

Eocardia perforata

Dicardia excavata ${ }^{b}$

Eocardia fissa $^{a}$

Schistomys erro

Phanomys mixtus

Hedymys integrus

Perimys erutus

Sphodromys scalaris

Perimys onustus

Sphiggomys zonatus

Prolagostomus pusillus

Prolagostomus divisus

Prolagostomus profluens

Prolagostomus imperialis

Sphaeromys irruptus ${ }^{11}$

Scotaeumys imminutus ${ }^{12}$

Pliolagostomus notatus

Scleromys angustus

Calladontomys vastatus
Pliolagostomus notatus ${ }^{13}$

Scleromys angustus

Nomen dubium ${ }^{14}$

${ }^{1}$ Arnal and Vucetich (2015b); ${ }^{2}$ Arnal et al. (2017); ${ }^{3}$ this work; ${ }^{4}$ Kramarz (2006b); ${ }^{5}$ Pérez (2010b); ${ }^{6}$ sensu Wood and Patterson (1959); ${ }^{7}$ Kramarz (2002);

${ }^{8}$ Ameghino (1894) transferred this species to Perimys zonatus; ${ }^{9}$ Candela and Nasif (2006) synonymized this species with Neoreomys; ${ }^{10}$ Rasia (2016);

${ }^{11} \mathrm{Scott}$ (1905) synonymized this species with Prolagostomus pusillus; ${ }^{12} \mathrm{Kramarz}(2002)$ synonymized this species with Prolagostomus; ${ }^{13}$ Rasia and Candela (2019); ${ }^{14}$ Mones. 
Trelew, Argentina; and Princeton University Collection of the Yale Peabody Museum (YPM-PU), New Haven, USA.

Caviomorph systematics follow Pérez (2010a,b), Arnal (2012), Arnal and Vucetich (2015b), Rasia (2016), and references in Table 1.

The studied localities along the southern banks of the RSC are, from East to West (Fernicola et al., 2014; Cuitiño et al., 2016, 2019) (Fig. 1): Barrancas Blancas (BB; 17.21-16.3 $\mathrm{Ma})$, with two sites, Estancia Aguada Grande (EAG) and Estancia Santa Lucía (ESL); Segundas Barrancas Blancas (SBB; 16.47-15.3 Ma), with three sites, Estancia Cordón Alto1 (ECA), Estancia Cordón Alto2 (ECA2), and Estancia el Tordillo (EET); Yaten Huageno (YH; 17.21-16.68 Ma) with one site, Estancia El Refugio (EER).

\section{SYSTEMATIC PALEONTOLOGY}

Order Rodentia Bowdich, 1821

Suborder HystRICOGNATHI Tullberg, 1899

Superfamily OctodontoIdEA Waterhouse, 1839

Genus Spaniomys Ameghino, 1887a

Type species. Spaniomys riparius Ameghino, 1887a. Pinturas Formation, Early Miocene and Santa Cruz Formation, Early-Middle Miocene, Province of Santa Cruz.

Spaniomys riparius Ameghino, 1887a

Referred materials. See Appendix 1.

Locality and Horizon. See Appendix 1.

Spaniomys sp.

Figure 2.1-4

Referred materials. See Appendix 1.

Locality and Horizon. See Appendix 1.

Comments. Spaniomys is characterized by being higher crowned than Acaremys Ameghino, 1887a and Acarechimys Patterson in Kraglievich, 1965. Cheek teeth have planar occlusal surfaces and undifferentiated cusps (Fig. 2.1-3), unlike Acarechimys, but resembling Adelphomys Ameghino, 1887a and Stichomys Ameghino, 1887a. This genus retains the deciduous premolar through life, unlike acaremyids
(= Acaremys, Sciamys Ameghino, 1887a, Pseudoacaremys Arnal and Vucetich, 2015b, Galileomys Vucetich and Kramarz, 2003, and Platypittamys Wood, 1949; Arnal and Vucetich 2015b). Lophs and lophids are thin with pointed labial and lingual ends respectively, unlike Adelphomys and Stichomys. Lower cheek teeth have four lophids (MPM-PV 20178; Fig. 2.1-2) and upper cheek teeth have four (MPM-PV 20310; Fig. 2.3) or five lophs.

Ameghino recognized three species: S. riparius, S. modestus Ameghino, 1887a, and S. biplicatus Ameghino, 1894 that differ in size and in the number of flexi on lower cheek teeth. However, size differences are not great. In this work, several well-preserved specimens were recognized as S. riparius owing to their slightly larger size (MPM-PV 20115, MPMPV 20524, MPM-PV 20557; Appendix 1; Tab. 2), but most of them (Fig. 2.1-4) were recognized as Spaniomys sp. (MPMPV 20562; MPM-PV 20618; MPM-PV 20770; Appendix 1; Tab. 2) until a systematic revision is performed. Within the new rodents sample, Spaniomys is present and abundant in EAG and ESL (BB) and ECA, ECA2, and EET (SBB). In EER (YH) rodents are very scarce, but it is represented by one specimen (MPM-PV 20770; Tab. 2).

Genus Stichomys Ameghino, 1887a

Type species. Stichomys regularis Ameghino, 1887a. Pinturas Formation, Early Miocene, and Santa Cruz Formation, Early-Middle Miocene, Province of Santa Cruz; Río Frías Formation, Middle Miocene, Province of Chubut.

Stichomys regularis Ameghino, 1887a

Figure 2.5-6, 9-10

Referred materials. See Appendix 1.

Locality and Horizon. See Appendix 1.

\section{Stichomys sp.}

Figure 2.7-8

Referred materials. See Appendix 1.

Locality and Horizon. See Appendix 1.

Stichomys? sp. 
TABLE 2 - Caviomorph rodents reported in this contribution with a comparison of the taxonomic richness between the Río Santa Cruz localities

\begin{tabular}{|c|c|c|c|c|c|c|c|}
\hline Taxa & & $n$ & $B B$ & $n$ & $S B B$ & $n$ & $Y H$ \\
\hline \multirow[t]{15}{*}{ Octodontoidea } & Spaniomys riparius & $x$ & 1 & $x$ & 6 & & \\
\hline & Spaniomys sp. & $x$ & 18 & $x$ & 38 & $x$ & 1 \\
\hline & Stichomys regularis & & & $x$ & 14 & $x$ & 1 \\
\hline & Stichomys $s p$. & $x$ & 7 & $x$ & 28 & & \\
\hline & Acarechimys minutus & & & $x$ & 5 & & \\
\hline & Acarechimys minutissimus & $x$ & 1 & $x$ & 14 & & \\
\hline & Acarechimys constans & & & $x$ & 7 & & \\
\hline & Acarechimys gracilis & & & $x$ & 6 & & \\
\hline & Dudumus sp. nov.? & & & $x$ & 1 & & \\
\hline & Prospaniomys sp. nov.? & $x$ & 1 & $x$ & 2 & & \\
\hline & Acaremys murinus & & & $x$ & 2 & & \\
\hline & Acaremys $s p$. & $x$ & 2 & $x$ & 1 & & \\
\hline & Sciamys principalis & $x$ & 2 & $x$ & 10 & & \\
\hline & Sciamys latidens & & & $x$ & 1 & & \\
\hline & Sciamys $s p$. & $x$ & 1 & $x$ & 4 & & \\
\hline \multirow[t]{3}{*}{ Erethizontoidea } & Steiromys detentus & $x$ & 1 & $x$ & 5 & & \\
\hline & Steiromys duplicatus & $x$ & 11 & $x$ & 1 & & \\
\hline & Steiromys $s p$. & $x$ & 2 & & & & \\
\hline \multirow[t]{7}{*}{ Cavioidea } & Neoreomys australis & $x$ & 51 & $x$ & 66 & $x$ & 1 \\
\hline & Phanomys mixtus & $x$ & 13 & & & & \\
\hline & Phanomys sp. & & & $x$ & 4 & & \\
\hline & Eocardia montana & $x$ & 8 & $x$ & 22 & & \\
\hline & "Eocardia" excavata & $x$ & 5 & $x$ & 4 & & \\
\hline & Eocardia $s p$ & $x$ & 22 & $x$ & 32 & & \\
\hline & Schistomys erro & & & $x$ & 3 & & \\
\hline \multirow[t]{8}{*}{ Chinchilloidea } & Prolagostomus pusillus & & & $x$ & 34 & & \\
\hline & Prolagostomus sp. & $x$ & 2 & $x$ & 80 & & \\
\hline & Pliolagostomus notatus & & & $x$ & 37 & & \\
\hline & Perimys erutus & $x$ & 11 & $x$ & 3 & & \\
\hline & Perimys onustus & $x$ & 1 & $x$ & 23 & & \\
\hline & Perimys incavatus & $x$ & 1 & & & & \\
\hline & Perimys $s p$. & $x$ & 7 & $x$ & 6 & & \\
\hline & Scleromys sp. & $x$ & 8 & $x$ & 4 & & \\
\hline
\end{tabular}

BB, barrancas Blancas; SBB, Segundas Barrancas Blancas; YH, Yaten Huageno; $n$, number of specimens (see Appendix 1). *Dubious taxa (?) are not included in the table.

Referred materials. See Appendix 1.

Locality and Horizon. See Appendix 1.

\section{Stichomys sp./Adelphomys sp.}

Referred materials. See Appendix 1.

Locality and Horizon. See Appendix 1.

Comments. Stichomys is characterized by being relatively high-crowned, resembling Adelphomys and Spaniomys in this respect. It has derived cheek teeth with planar occlusal surfaces, undifferentiated cusps, and retention of the deciduous premolars through life (Fig. 2.5-10), also as in Adelphomys and Spaniomys. Nevertheless, their cheek teeth have broader lophs/ids with rounded end tips (Fig. 2.5-7 and 2.9), as Adelphomys and unlike Spaniomys. Upper molars with four lophs and lowers with three main lophids, as 
in Adelphomys and Spaniomys. Adelphomys is very similar to Stichomys. The two genera differ in that the former has planar anterior face on the incisors and the latter convex ones (Ameghino, 1887a). In general terms, Stichomys is more abundant than Adelphomys (convex incisors are more abundant than planar incisors; see Appendix 1). Nevertheless, in the new rodent collection several specimens have no incisors preserved, and thus, they could not be recognized at generic level. These specimens were referred to as Stichomys sp./Adelphomys sp. (MPM-PV 20356, MPM-PV 20550; Appendix 1).

Seven species of Stichomys were described (Ameghino, 1887a, 1891a). Three of them were transferred to Acarechimys (Arnal et al., 2017). The remaining species require taxonomic revision. At present, we recognize several large and well-preserved specimens as S. regularis (Fig. 2.5-6, 9-10), but the remaining specimens only as Stichomys sp. (MPM-PV 20415; Fig. 2.7-8).

Within the new rodent sample Stichomys is the most abundant octodontoid with more than 60 specimens (Appendix 1). We identified Stichomys regularis, Stichomys sp., Stichomys sp./Adelphomys sp., and Stichomys? sp. (Appendix 1). These taxa are more abundant in ECA, ECA2, and EET (SBB), while in $B B$ ( $E S L$ and $E A G$ ) they are only represented by three specimens recognized as Stichomys sp. (Tab. 2). In EER (YH) there is one specimen recognized as Stichomys regularis (MPM-PV 20771). The phylogenetic relationships of Stichomys and Adelphomys are not clear. Based on the dental morphology they have been included in "Adelphomyinae", an echimyid fossil lineage (Wood and Patterson, 1959; Kramarz, 2001). Nevertheless, most phylogenetic analyses (Arnal et al., 2014; Arnal and Vucetich, 2015a; Verzi et al., 2014) do not recover this clade. In fact, both Stichomys and Adelphomys, together with Spaniomys and other fossil octodontoids (i.e., Eodelphomys Frailey and Campbell, 2004 from the late Eocene? of Peru and Xylechimys Patterson and Pascual, 1968 from the late Oligocene of Patagonia), represent a basal radiation of crown-octodontoids (Arnal and Vucetich, 2015a).

Genus Acarechimys Patterson in Kraglievich, 1965

Type species. Acaremys minutus Ameghino, 1887a. Santa Cruz
Formation, Early-Middle Miocene, Province of Santa Cruz; Collon Curá Formation, early Middle Miocene, Province of Neuquén; unnamed formation, late Middle Miocene, Quebrada Honda, Bolivia.

Acarechimys minutus (Ameghino, 1887a)

Figure 2.11-13

Referred materials. See Appendix 1.

Locality and Horizon. See Appendix 1.

Acarechimys minutissimus (Ameghino, 1887a)

Referred materials. See Appendix 1.

Locality and Horizon. See Appendix 1.

Acarechimys constans (Ameghino, 1887a)

Referred materials. See Appendix 1.

Locality and Horizon. See Appendix 1.

Acarechimys gracilis (Ameghino, 1891)

Figure 2.14-15

Referred materials. See Appendix 1.

Locality and Horizon. See Appendix 1.

Comments. Acarechimys was a successful evolutionary lineage of octodontoids with brachydont cheek teeth, thin loph/lophids, and identifiable cusps, unlike Stichomys, Adelphomys, and Spaniomys. It retained the deciduous premolars through life (Fig. 2.11, 14), unlike acaremyids. Upper cheek teeth have four lophs (Fig. 2.11) and lowers have three main lophids with another variably developed (Fig. 2.14; Arnal et al., 2017). This genus represents the octodontoid with the widest temporal (Late Oligocene-Late Miocene) and geographic distribution (southern Argentinean Patagonia to Colombia), reaching its maximum recorded diversity in the Santacrucian (Arnal et al., 2017). Five species are recognized: A. leucotheae Vucetich et al., 2014 (Late Oligocene, Province of Chubut), A. minutus, A. minutissimus (Early-Middle Miocene of Argentinean Patagonia, Bolivia, and Colombia), A. constans and $A$. gracilis (Early-Middle Miocene, provinces of Chubut and Santa Cruz, Argentina). For detailed descriptions of the species see Arnal et al. (2017). 
Acarechimys is represented in all the stratigraphic levels of SBB (Appendix 1). Four of the five known species are recorded: A. minutus (MPM-PV 15088, MPM-PV 15089; Fig. 2.11-13), A. minutissimus (MPM-PV 15100, MPM-PV 20069, MPM-PV 20346; see Appendix 1), A. constans (MPM-PV 15093, MPM-PV 15096, MPM-PV 20637; see Appendix 1), and A. gracilis (MPM-PV 17430; Fig. 2.14-15). On the other hand, only one specimen of $A$. minutissimus is recorded in BB (MPM-PV 20069; EAG-80 mts) and none in $\mathrm{YH}$.

Genus Dudumus Arnal et al., 2014

Type and only species. Dudumus ruigomezi Arnal et al., 2014. Sarmiento Formation, Trelew Member, Early Miocene, Province of Chubut.

\section{Dudumus sp. nov.?}

Figure 2.16

Referred material. MPM-PV 20561, right M1-M2.

Locality and horizon. Segundas Barrancas Blancas (ECA2), Río Santa Cruz, Province of Santa Cruz, Early-Middle Miocene. Comments. One small maxillary fragment with $\mathrm{M} 1-\mathrm{M} 2$ is here assigned to Dudumus sp. nov.? The molars are bunolophodont, brachydont, and slightly terraced (Fig. 2.16), as in Dudumus ruigomezi and Caviocricetus Vucetich and Verzi, 1996. As in Dudumus ruigomezi and Caviocricetus, the third loph, interpreted as a mesolophule, is shorter than the remaining lophs and does not reach the metacone. The length of this crest and the degree of terracing in the molars are more similar in these respects to Dudumus ruigomezi than to Caviocricetus. Nevertheless, the new specimen has different teeth proportions and therefore is here interpreted as a possible new species.

MPM-PV 20561 (Fig. 2.16) was found in ECA2 of SBB locality (Tab. 2). It represents the first record of Dudumus for the Santa Cruz Formation, since it was previously known for Colhuehuapian (Early Miocene) of the Province of Chubut.

\section{Genus Prospaniomys Ameghino, 1902}

Type species. Prospaniomys priscus Ameghino, 1902. Sarmiento Formation, Early Miocene, Province of Chubut.

\section{Prospaniomys sp. nov.?}

Figure 2.17-18

Referred materials. See Appendix 1.

Locality and horizon. Barrancas Blancas (ESL) and Segundas Barrancas Blancas (ECA2), Río Santa Cruz, Province of Santa Cruz, Early-Middle Miocene.

Comments. Three bunolophodont specimens are identified as Prospaniomys sp. nov.? MPM-PV 20294 (Fig. 2.17) is a right maxillary fragment with DP4-M1 and MPM-PV 20560 is an isolated upper molar. These cheek teeth have four lophs of which the anterior most (= anteroloph) does not contact the paracone and the third and fourth lophs are labially fused to the metacone, delimiting a posterior fossette (Fig. 2.17), unlike Protacaremys Ameghino, 1902. MPM-PV 20207 (Fig. 2.18) is an isolated lower molar that has four thin lophids and acuminated labial cuspids, as in Prospaniomys priscus and unlike Protacaremys. Nevertheless, these specimens seem to be a new species since they are smaller than the type species and have slightly higher crowns.

These new findings are remarkable since Prospaniomys was previously only recognized in Colhuehuapian sediments (Early Miocene) of the Province of Chubut. MPM-PV 20207 was recorded in ESL (BB); and MPM-PV 20294 and MPMPV 20560 were found in ECA2 from SBB (Tab. 2; Appendix 1).

Family ACAREMYIDAE Wood, 1949

Genus Acaremys Ameghino, 1887a

Type species. Acaremys murinus Ameghino, 1887a. Sarmiento Formation, Colhue Huapi Member, Early Miocene, Province of Chubut; Pinturas Formation, upper sequence, late Early Miocene, and Santa Cruz Formation, Early-Middle Miocene, Province of Santa Cruz.

Acaremys murinus Ameghino, 1887a

Referred materials. See Appendix 1. Locality and Horizon. See Appendix 1.

\section{Acaremys sp.}

Referred material. See Appendix 1. 
Locality and Horizon. See Appendix 1.

Comments. Acaremys, Sciamys and other octodontoids are grouped within Acaremyidae, the only extinct octodontoid family recognized (Arnal and Vucetich, 2015b). Acaremys is lower-crowned than Sciamys and higher-crowned than Galileomys and Platypittamys. Cheek teeth have discernible cusps, relatively thin lophs/ids, and replace the deciduous premolars with age, unlike most fossil octodontoids. Upper and lower molars have four main lophs/ids, unlike Acarechimys. Acaremys is recognized by three valid species: A. murinus, A. messor Ameghino, 1889 and A. major Scott, 1905 (Early-Middle Miocene, Province of Santa Cruz). For a detailed description of these species see Arnal and Vucetich (2015b).

Within the new rodent sample, Acaremys is represented in ESL from BB by Acaremys sp. (MPM-PV 20175, MPM-PV 20216; Tab. 2); in SBB by $A$. murinus in ECA (MPM-PV 20272) and ECA2 (MPM-PV 20538), and by Acaremys sp. in ECA2 (MPM-PV 20653) (Tab. 2).

Genus Sciamys Ameghino, 1887a

Type species. Sciamys principalis Ameghino, 1887a. Pinturas Formation, upper sequence, late Early Miocene and Santa Cruz Formation, Early-Middle Miocene, Province of Santa Cruz.

Sciamys principalis Ameghino, 1887a

Figure 2.19-20

Referred materials. See Appendix 1.

Locality and horizon. See Appendix 1.

\section{Sciamys latidens Scott, 1905}

Figure 2.21-22

Referred material. MPM-PV 20668, right mandible with p4-m2.

Locality and horizon. Segundas Barrancas Blancas (ECA2), Río Santa Cruz, Province of Santa Cruz. Early-Middle Miocene.

\section{Sciamys sp.}

Referred materials. See Appendix 1. Locality and horizon. See Appendix 1.
Comments. Sciamys is similar to Acaremys, but differs in having higher crowns and less discernible cusps. As in Acaremys, it has upper and lower molars with four lophs/ids and replaces the deciduous premolar through life. Sciamys is more abundant than Acaremys (Appendix 1) and it is recognized by at least six species: S. principalis, S. varians Ameghino, 1887a, S. robustus Ameghino, 1894, S. rostratus Scott, 1905, S. latidens Scott, 1905 (Early-Middle Miocene, Province of Santa Cruz), and S. petisensis Arnal and Pérez, 2013 (MiddleLate Miocene, Province of Chubut).

Within the new rodent sample, the genus is present but scarce at EAG (Sciamys principalis and Sciamys sp.) of BB, but absent in ESL (Tab. 2). On the contrary, it is very abundant in SBB, especially in ECA2 where S. principalis, S. latidens, and Sciamys sp. have been identified (Tab. 2; Appendix 1). The genus is absent in $\mathrm{YH}$. A notably new record for the RSC is the presence of Sciamys latidens in ECA2 (MPM-PV 20668; Fig. 2.19-20). This species is well-characterized by having a molarized posterior portion of the p4 (Fig. 2.19), as in Sciamys petisensis and unlike all the remaining Early Miocene species, and was previously known only for Killik Aike, coastal Santa Cruz Province, Argentina (Scott, 1905; Fig. 1).

Several specimens could not be recognized at generic level and are listed as Acaremyidae (Appendix 1).

Superfamily ERETHIzONTOIDEA Simpson, 1945

Family ERETHIZONTIDAE Thomas, 1897

Genus Steiromys Ameghino, 1887a

Type species. Steiromys detentus Ameghino, 1887a. Santa Cruz Formation, Early-Middle Miocene, Province of Santa Cruz.

Steiromys detentus Ameghino, 1887a

Figure 3.23-24

Referred materials. See Appendix 1.

Locality and horizon. See Appendix 1.

Steiromys duplicatus Ameghino, 1887a

Referred material. see Appendix 1.

Locality and horizon. See Appendix 1. 

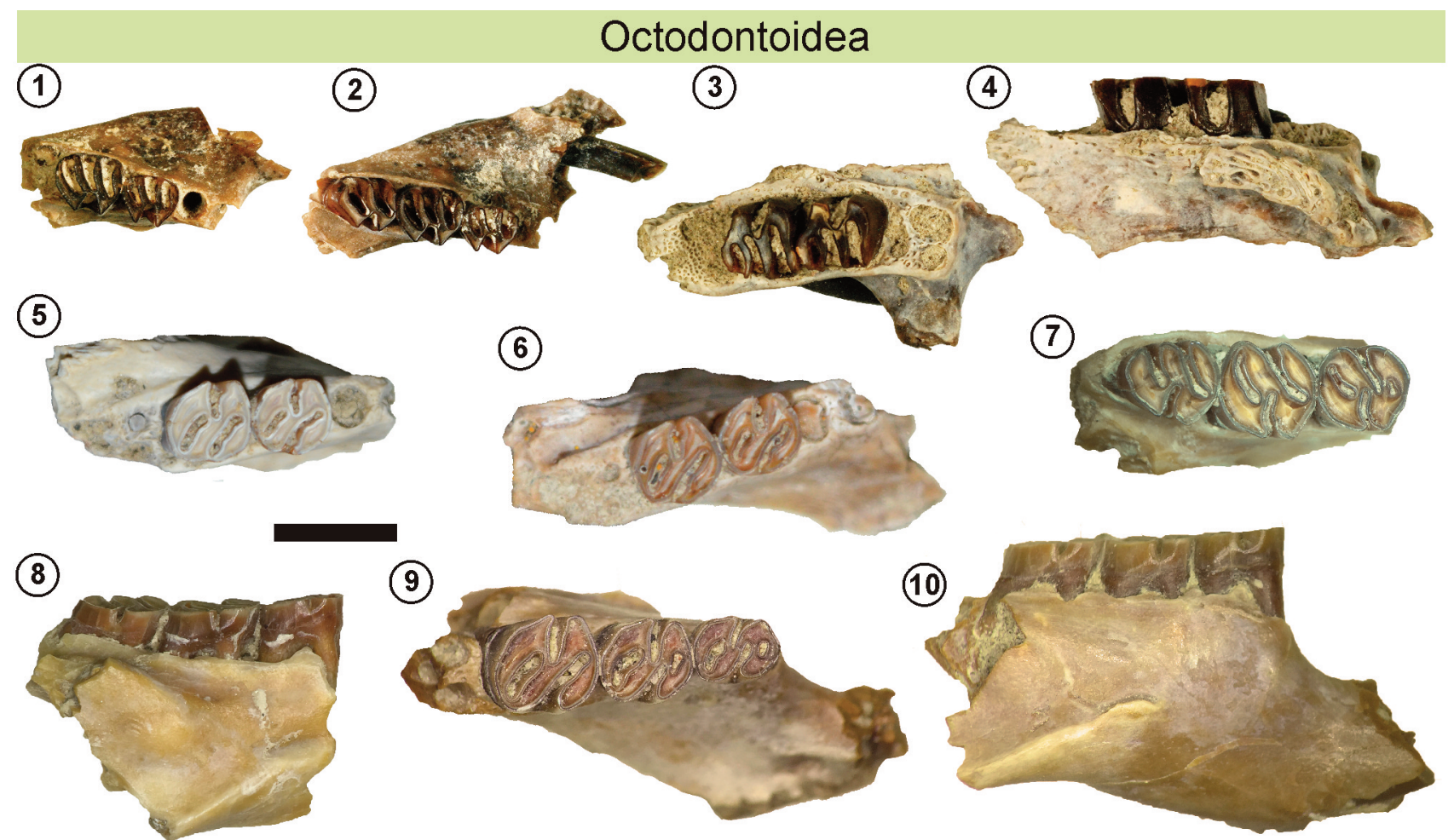

(9)
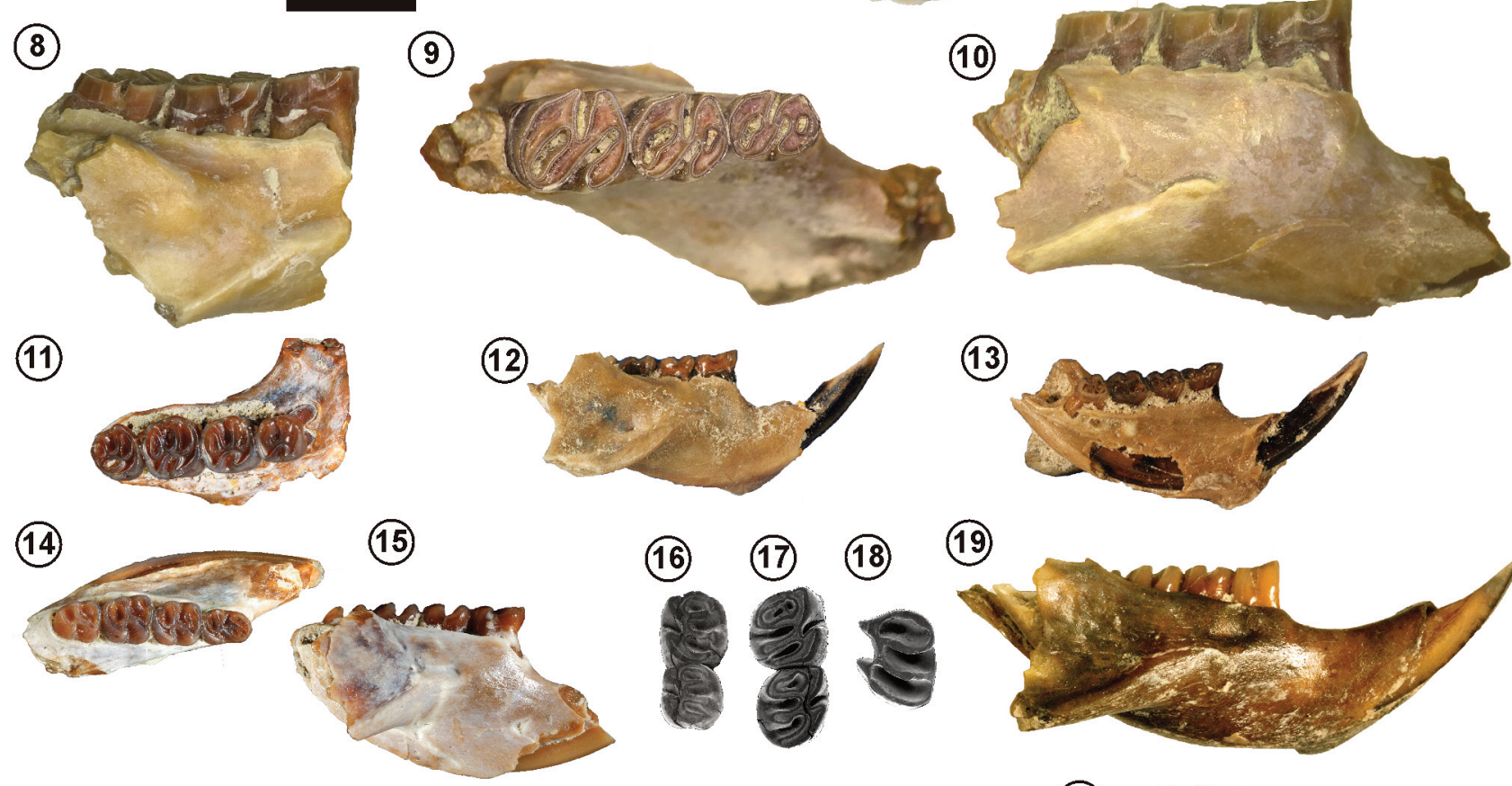

(20)

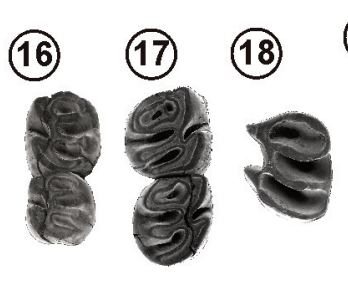

(13)

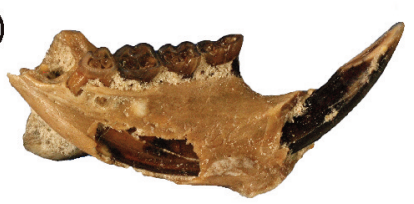

(19)

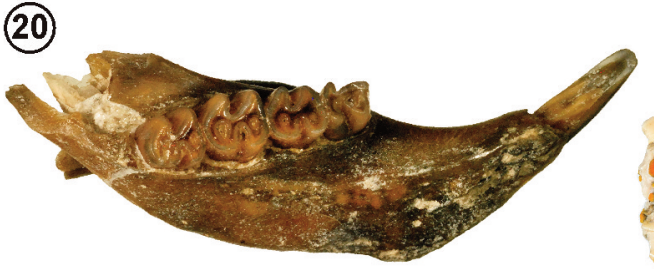

(21)
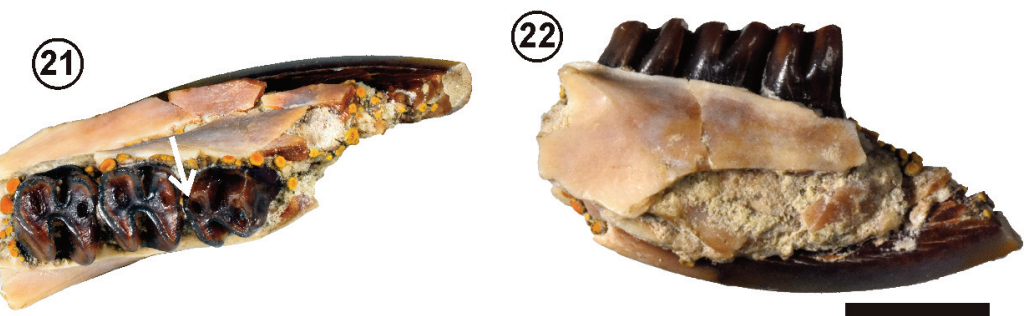

\section{Erethizontoidea}

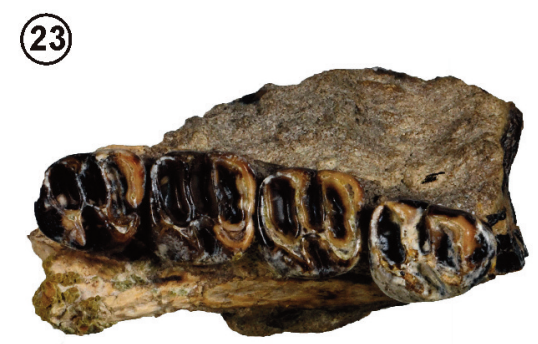

(24)

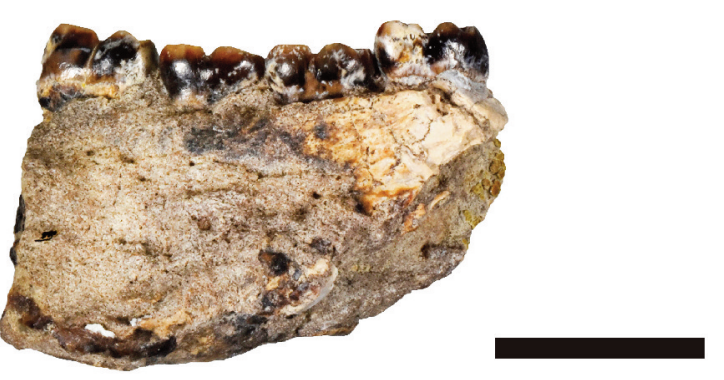




\section{Steiromys duplicatus?}

Referred materials. See Appendix 1. Locality and horizon. See Appendix 1.

\section{Steiromys sp.}

Referred materials. See Appendix 1.

Locality and horizon. See Appendix 1.

Comments. Erethizontids are medium-size caviomorphs. Extant and fossil erethizontids have generally conservative skull and dental morphologies, with low-crowns and bunolophodont to lophodont cheek teeth (Patton et al., 2015). They replace the deciduous premolars, with the exception of the extant Chaetomys Gray, 1843 (Patterson and Wood, 1982). In occlusal view the dentine in erethizontids has very thin enamel (Fig. 2.23), unlike octodontoids. Laterally, the molar crowns are bulging (Fig. 2.24). Steiromys is slightly higher-crowned than Eosteiromys Ameghino, 1902.

Within the new rodent sample, Steiromys detentus was found in EAG (MPM-PV 20058) from BB, and ECA (MPM-PV 20384) and ECA2 (MPM-PV 20598; MPM-PV 20652) from SBB (Tab. 2; Appendix 1). Upper molars have four main lophs and relatively well-individualized cusps (MPM-PV 20058). Lower cheek teeth have four lophids that wear the two anterior and the two posterior ones delimiting an anterior and posterior fossettid (Fig. 2.23). Molars are rectangular. The p4 is relatively longer than the molars, the anterior portion is labio-lingually shorter, and can bear four (MPM-PV 20442; Fig. 2.23) or five lophids (MPM-PV 20384). The incisors are robust with a plane anterior face. Steiromys duplicatus is less abundant, but was also recorded in EAG (MPM-PV 2008620095) from BB, and in ECA2 (MPM-PV 20630) from SBB (Appendix 1). This species differs from $S$. detentus in having five lophs in upper (MPM-PV 20087; MPM-PV 20630) and lower (MPM-PV 20094) molars.

Several broken teeth were recognized as Steiromys sp. in BB (MPM-PV 20096, MPM-PV 20097; Tab. 2; Appendix 1).

Superfamily CAVIOIDEA (Fischer de Waldheim, 1817)

Genus Neoreomys Ameghino, 1887a

Type species. Neoreomys australis Ameghino, 1887a. Santa Cruz Formation, Early-Middle Miocene, Province of Santa Cruz.

Neoreomys australis Ameghino, 1887a

Figure 3.1-3

Referred materials. See Appendix 1.

Locality and horizon. See Appendix 1.

Comments. Neoreomys is traditionally characterized by having hypsodont and rooted cheek teeth, more high crowned than in Dasyprocta llliger, 1811, Myoprocta Thomas, 1903, Asteromys Ameghino, 1897, and Luantus initialis Ameghino, 1902. Cheek teeth have more penetrating flexus/id with persistent fossettes/ids: the hypoflexus is joined to the paraflexus and the hypoflexid joined to a posteroflexid (Fig. 3.1). The enamel is continuous around the entire crown and cementum is present in the hypoflexus/id.

Ameghino recognized nine species of Neoreomys from the Santa Cruz Formation (Ameghino, 1887a; 1891; 1894). Scott (1905) considered only three of those to be valid. Fi-

Figure 2. Octodontoidea (1-22) and Erethizontoidea (23-24). 1-4, Spaniomys sp.; 1, MPM-PV 20182, right mandibular fragment with m1-m2 in occlusal view; 2, MPM-PV 20178, left mandible with m1-m3 and incisor in occlusal view (inverted); 3-4, MPM-PV 20310, left maxillary fragment with M1-M2 (inverted) in occlusal (3) and lingual (4) views; 5-6, Stichomys regularis; 5, MPM-PV 20237, left mandibular fragment with $\mathrm{m} 1-\mathrm{m} 2 ; 6$, MPM-PV 20276, left mandibular fragment with $\mathrm{m} 1-\mathrm{m} 2 ; 7-8$, Stichomys sp., MPM-PV 20415, left mandible with m1-m3 in occlusal (7) and labial (8) views; 9-10, Stichomys regularis, MPM-PV 20444, left mandible (inverted) in occlusal and ventral views; 11-13, Acarechimys minutus; 11, MPM-PV 15088, left maxilla with DP4-M3 in occlusal view (inverted); 12-13, MPM-PV 15089, right mandible in labial (12) and lingual (13) views; 14-15, Acarechimys gracilis, MPM-PV 17430, left mandible with dp4-m3 (inverted) in occlusal (14) and labial (15) views; 16, Dudumus sp. nov.? MPM-PV 20561, right DP4-M1; 17-18, Prospaniomys sp. nov.?; 17, MPM-PV 20294, right DP4-M1; 18, MPM-PV 20207, left lower molar; 19-20, Sciamys principalis, MPM-PV 20308, right mandible with p4-m3; 21-22, Sciamys latidens, MPM-PV 20668, right mandible with p4-m2; 23-24, Steiromys detentus MPM-PV 20442, right mandible in occlusal (23) and lingual (24) views. Anterior to right. Scale bars= $5 \mathrm{~mm}(1-15,19-22), 1 \mathrm{~mm}(16-18)$, and $10 \mathrm{~mm}(23-24)$. 
nally, Fields (1957) and later authors (e.g., Kramarz and Bellosi, 2005; Kramarz, 2006b; Pérez, 2010b; Vucetich et al., 2015) recognized Neoreomys australis as the sole species present in the Santa Cruz Formation. Other two species of Neoreomys have been described elsewhere in South America: Neoreomys huiliensis Fields, 1957 from Villavieja Formation (La Venta, Colombia) and N. pinturensis Kramarz, 2006b from the Pinturas Formation (Province of Santa Cruz, Argentina). Neoreomys australis is the largest and most abundant caviomorph (more than 120 specimens; see Appendix 1). An exhaustive revision of this genus (currently under study by MEP) is necessary to corroborate the taxonomic status of the species of Neoreomys, and its specific richness in the Santa Cruz Formation. Within the new rodent sample, Neoreomys is the only cavioid present in $\mathrm{YH}$, the oldest locality (Tab. 2). Moreover, this genus is well-represented in the other localities of the SCR: EAG and ESL from BB, and ECA, ECA2, and EET from SBB (Tab. 2; Appendix 1).

Genus Phanomys Ameghino, 1887a

Type species. Phanomys mixtus Ameghino, 1887a. Río Jeinemení Formation, Pinturas Formation and Santa Cruz Formation, EarlyMiddle Miocene, Province of Santa Cruz.

Phanomys mixtus Ameghino, 1887a

Figure $3.4-5$

Referred materials. See Appendix 1.

Locality and horizon. See Appendix 1.

\section{Phanomys sp.}

Referred materials. See Appendix 1.

Locality and horizon. See Appendix 1.

Comments. Phanomys is known by two species $P$. mixtus and $P$. vetulus Ameghino, 1894. Phanomys mixtus is represented by fragmentary maxillae, mandibles, and isolated teeth (Appendix 1). Phanomys is characterized by having highcrowned and rooted cheek teeth (with a greater degree of hypsodonty compared with other basal cavioids such as species of Luantus Ameghino, 1902), the presence of cementum in earlier stages of wear, relatively ephemeral fossettes/ids, and enamel discontinuities along the entire labial wall of upper cheek teeth and the lingual wall of lower cheek teeth (Fig. 3.4-5; for a detail description of the genus see Pérez and Vucetich, 2012).

Interestingly, in RSC Phanomys is much more abundant in EAG from BB, but its richness decreases while that of the euhypsodont cavioids (i.e., Schistomys) increases in ECA and ECA2 (SBB) (Tab. 2; Appendix 1).

Recent phylogenetic study suggests that Phanomys is the sister group of the euhypsodont cavioids. Additionally, $P$. mixtus was proposed as a useful biostratigraphic indicator because it was found in different Miocene localities of the Province of Santa Cruz (Pérez and Vucetich, 2012).

Genus Eocardia Ameghino, 1887b

Type species. Eocardia montana Ameghino, 1887b. Santa Cruz Formation, Early-Middle Miocene, Province of Santa Cruz.

Eocardia montana Ameghino, 1887b

Figure 3.6-9

Referred materials. See Appendix 1.

Locality and horizon. See Appendix 1.

"Eocardia" excavata Ameghino, 1891b

Figure 3.10

Referred materials. See Appendix 1.

Locality and horizon. See Appendix 1.

\section{Eocardia sp.}

Referred materials. See Appendix 1. Locality and horizon. See Appendix 1.

Comments. Eocardia was originally defined by Ameghino (1887b) and traditionally several species were included in this genus or subgenus (e.g., Ameghino, 1887a, 1891b, 1894, 1906; Scott, 1905). Pérez (2010b) reduced the nominal diversity of Santacrucian forms to three species: the type species Eocardia montana, "E." excavata and the smaller "E." fissa Ameghino, 1891a. Eocardia is characterized by having continuous growth of the cheek teeth without root formation, double and heart-shaped cheek teeth, ephemerous fossettes/ids, presence of cementum beginning at very 
early ontogenetic stages, and a narrow and discontinuous enamel layer surrounding the crown (Fig. 3.6-10). Eocardia is the only euhypsodont cavioid whose upper premolar has only one lobe (Fig. 3.6). The new RSC remains are assigned to E. montana, "E." excavata, and Eocardia sp. (Tab. 2). It is interesting to note that although " $E$." fissa has not been recorded in the new collections, this species was mentioned as coming from the RSC by Ameghino (1891; Pérez, 2010).

Eocardia is present at EAG and ESL from BB, and ECA, ECA2, and EET from SBB.

Genus Schistomys Ameghino, 1887a

Type species. Schistomys erro Ameghino, 1887a. Santa Cruz Formation, Early-Middle Miocene, Province of Santa Cruz.

\section{Schistomys erro Ameghino, 1887a}

Figure 3.11

Referred materials. See Appendix 1.

Locality and horizon. See Appendix 1.

Comments. Schistomys was established by Ameghino (1887a); later, additional species were assigned to this genus (Ameghino, 1891; Scott, 1905). Currently, only two species are considered valid (Pérez, 2010): the type species Schistomys erro and S. rollinsii (Scott, 1905). Schistomys is characterized by the same morphological characters as Eocardia, however they differ in that the upper premolar (P4) has two well-developed lobes similar to those of molars (Fig. 3.11). The only species recorded at SCR is $S$. erro which is present at ECA2 and EET from SBB (Tab. 2; Appendix 1).

It should be noted that in ECA2 (SBB), where the abundance of Phanomys is lower, Schistomys appears for the first time at SCR (Tab. 2). Whereas in EET, where Schistomys abundance is greater, Phanomys is not recorded.

\section{Superfamily CHInCHILLOIDEA Bennett, 1833 \\ Family CHINCHILLIDAE Bennett, 1833}

Genus Prolagostomus Ameghino, 1887a

Type species. Prolagostomus pusillus Ameghino, 1887a. Santa Cruz Formation, Early-Middle Miocene, Province of Santa Cruz.

\section{Prolagostomus pusillus Ameghino, 1887a}

Referred materials. See Appendix 1.

Locality and horizon. See Appendix 1.

\section{Prolagostomus sp.}

Figure 3.12

Referred materials. See Appendix 1.

Locality and horizon. See Appendix 1.

Comments. Prolagostomus is a small to medium sized caviomorph, similar to Pliolagostomus Ameghino, 1887a. The upper and lower cheek teeth are euhypsodont and bilophodont, with the exception of the M3, which has three lophs. The hypoflexus/id are narrower than in Perimys Ameghino, 1887a, but broader than in Lagostomus Brookes, 1828. Molar crown walls are more curved and hypoflexid is more sinuous (Fig. 3.12) than in Pliolagostomus. The anterior lophid of lower molars is more labially extended (Fig. 3.12), unlike Perimys. The $\mathrm{p} 4$ is more obliquely oriented than molars (Fig. 3.12), unlike Pliolagostomus.

Prolagostomus is in general more abundant than Pliolagostomus (Appendix 1). Within the new rodent sample this genus is relatively well-represented in ECA, ECA2, and EET from SBB (Tab. 2; Appendix 1). It is only represented by two broken molars of Prolagostomus sp. (MPM-PV 20231, MPM-PV 20232; Tab. 2) in ESL from BB and is absent in $\mathrm{YH}$.

Genus Pliolagostomus Ameghino, 1887a

Type species. Pliolagostomus notatus Ameghino, 1887a. Santa Cruz Formation, Early-Middle Miocene, Province of Santa Cruz.

Pliolagostomus notatus Ameghino, 1887a

Referred materials. See Appendix 1.

Locality and horizon. See Appendix 1.

Comments. Pliolagostomus is a small to medium sized caviomorph, similar to Prolagostomus. Upper and lower cheek teeth are euhypsodont and bilophodont, with the exception of the M3 which has three lophs. Cheek-tooth crown walls are straighter than Prolagostomus. Hypoflexus/ 

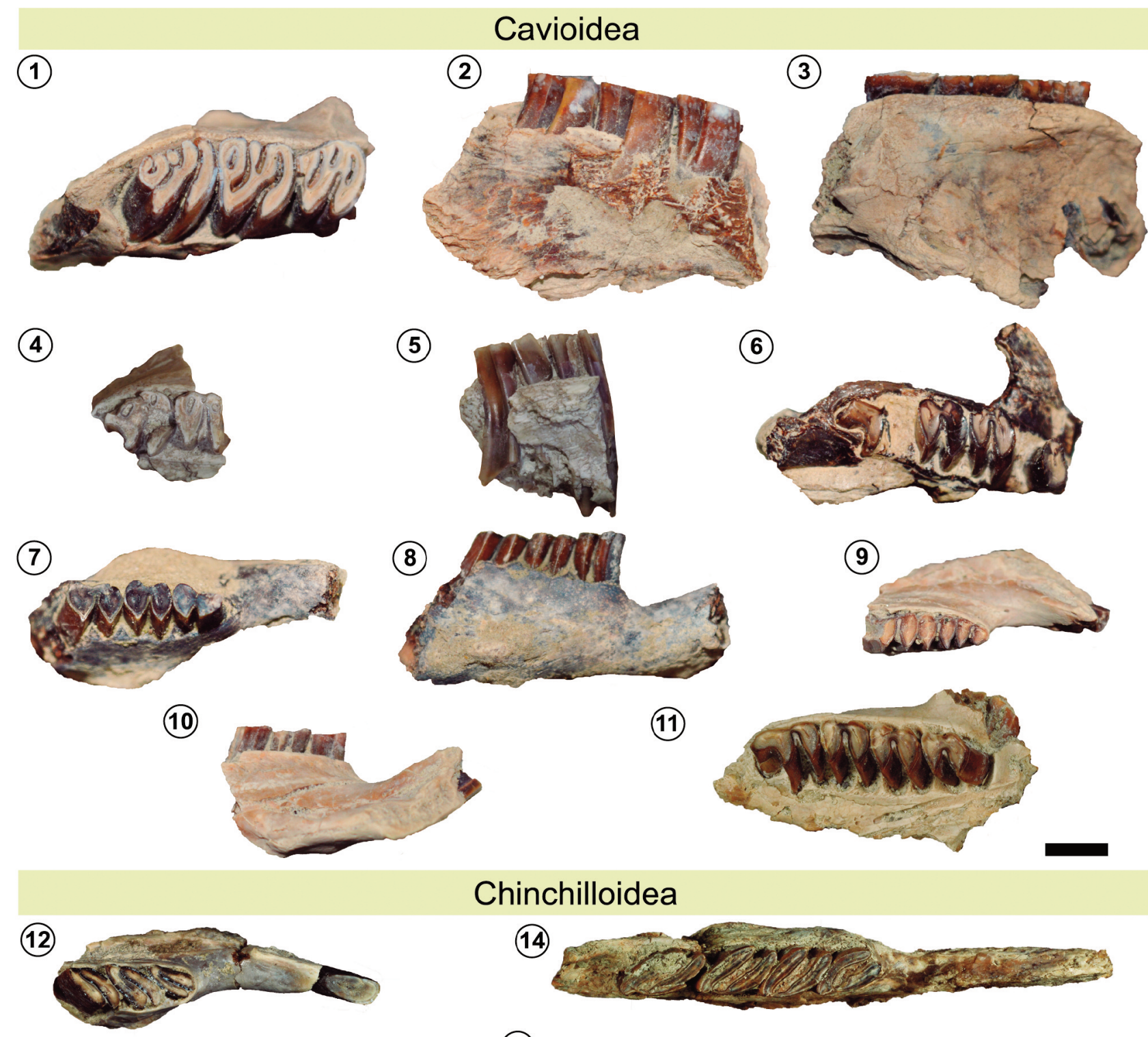

(13)

Chinchilloidea

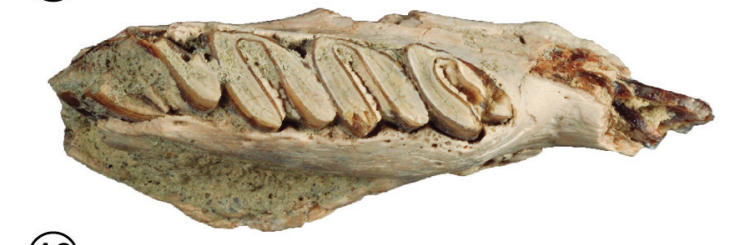

(16)

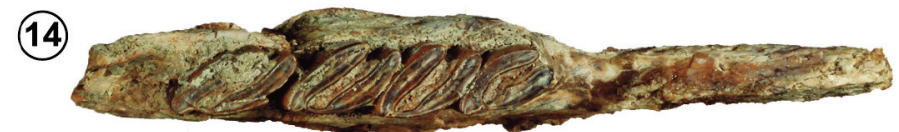

(15)
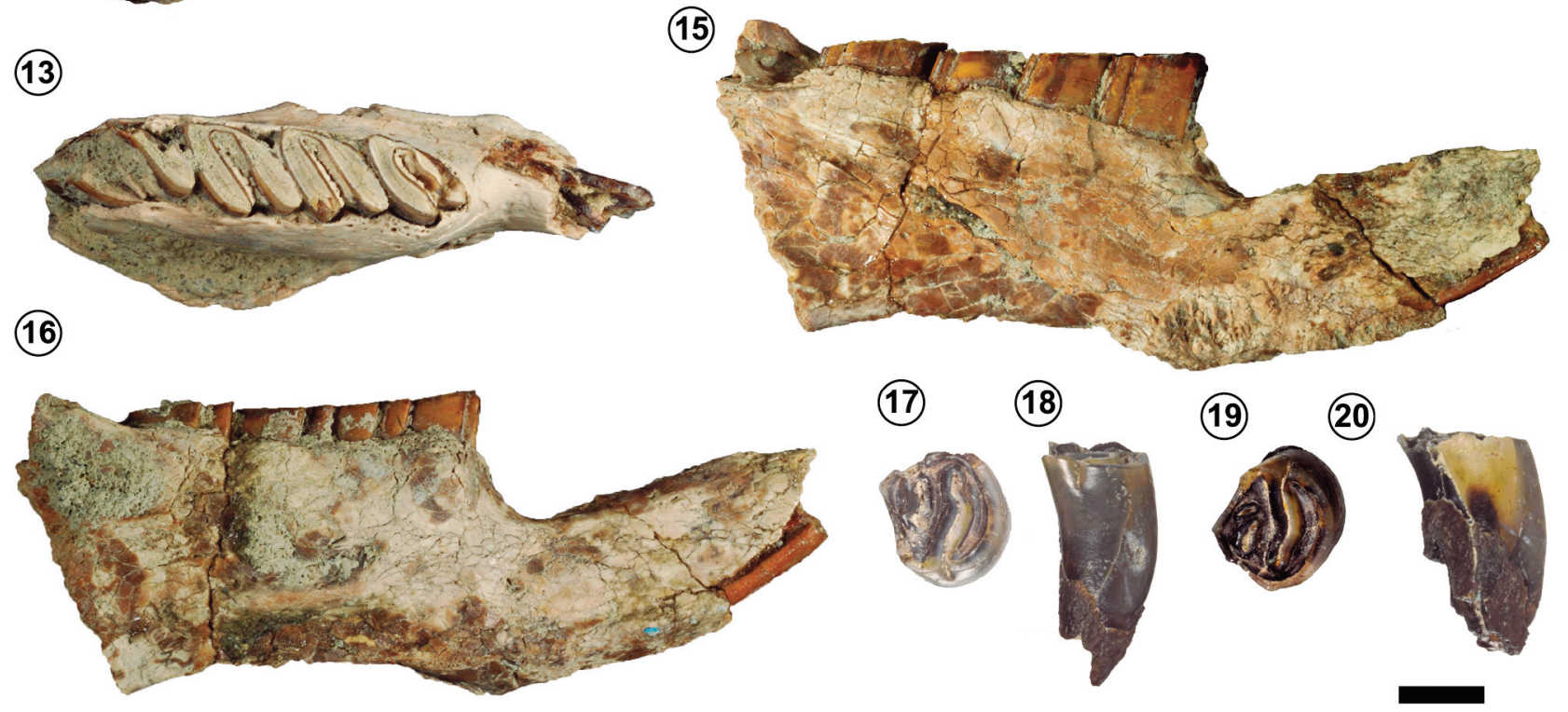

(17) (18)

(19) (20)
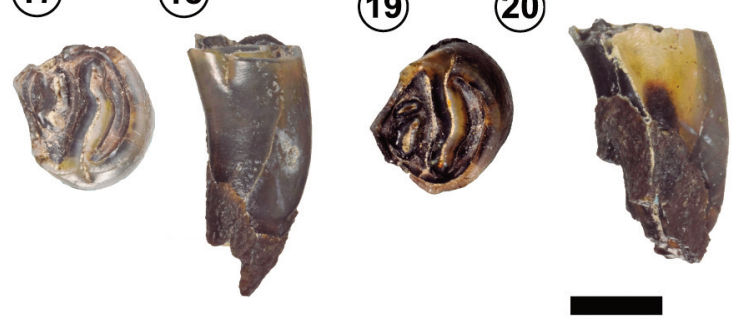
id is narrow, as in Prolagostomus. For a detailed description of this species see Rasia and Candela (2019).

As in Prolagostomus, this species is relatively well-represented in the three sites of SBB (ECA, ECA2, and EET; Tab. 2; Appendix 1). Notably, it is absent in BB and YH. Several specimens could not be identified at generic level and were assigned to Prolagostomus sp./Pliolagostomus sp. (MPM-PV 20259, MPM-PV 20349, MPM-PV 20381; Appendix 1).

Family NeoepiBlemidae Kraglievich, 1926

Genus Perimys Ameghino, 1887a

Type species. Perimys erutus Ameghino, 1887a. Pinturas Formation, Early Miocene, and Santa Cruz Formation, Early-Middle Miocene, Province of Santa Cruz.

Perimys erutus Ameghino, 1887a

Figure 3.13

Referred materials. See Appendix 1.

Locality and horizon. See Appendix 1.

Perimys onustus Ameghino, 1887a

Figure 3.14-16

Referred materials. See Appendix 1.

Locality and horizon. See Appendix 1.

Perimys incavatus Ameghino, 1902

Referred materials. See Appendix 1.

Locality and horizon. See Appendix 1.

\section{Perimys sp.}

Referred materials. See Appendix 1.

Locality and horizon. See Appendix 1.

Comments. Perimys is a medium to large sized caviomorph. Cheek teeth are protohypsodont, unlike Prolagostomus and Pliolagostomus. Upper and lower cheek teeth are bilophodont, with the exception of the M3 which has three lophs, as in Prolagostomus and Pliolagostomus. Nevertheless, Perimys differs in that this third loph is parallel to the anterior two lophs, and in that the hypoflexus/id are conspicuously broader and filled with more cementum. Thus, these teeth have a U-shape occlusal surface (Fig. 3.13-16).

The genus was abundantly recovered in both in BB and $\mathrm{SBB}$, but notably, the largest species, $P$. onustus, is very abundant in SBB, while in BB it is represented by a single specimen (MPM-PV 20160), and the small species, P. incavatus, is more abundant in BB (Tab. 2; Appendix 1).

Family DinomyıdAe Alston, 1876

Genus Scleromys Ameghino, 1887a

Scleromys angustus. Ameghino, 1887a. Santa Cruz Formation, Early-Middle Miocene, Province of Santa Cruz.

\section{Scleromys sp.}

Figure 3.17-20

Referred materials. See Appendix 1.

Locality and horizon. See Appendix 1.

Comments. Among the species of Scleromys recognized in

Figure 3. Cavioidea (1-11) and Chinchilloidea (12-17). 1-3, Neoreomys australis MPM-PV 20292, right maxillary fragment with M1-M3 in occlusal, lingual, and labial views; 4-5, Phanomys mixtus MPM-PV 20048, right maxilla with M2-M3 in occlusal and lingual views; 6, Schistomys erro MPM-PV 20529, right maxilla with P4-M3 in occlusal view; 7, "Eocardia" excavata MPM-PV 20241, right maxilla with P4-M3 in occlusal view; 8-9, Eocardia montana MPM-PV 20401, left mandible with p4-m2 in occlusal and labial views (inverted); 10-11, Eocardia montana MPMPV 20053, right mandible with p4-m2 in occlusal and lingual views; 12, Prolagostomus sp. MPM-PV 20314, right mandible with p4-m2 in occlusal view; 13, Perimys erutus MPM-PV 20671, right mandible with p4-m3 in occlusal view; 14-16, Perimys onustus MPM-PV 20670, left mandible with p4-m3 in occlusal, lingual and labial views (inverted); 17-18, Scleromys sp. MPM-PV 20098, left upper molar; 19-20, Scleromys sp. MPM-PV 20099, left upper molar. Anterior to the right. Scale bars= $5 \mathrm{~mm}(1-13), 7.5 \mathrm{~mm}(14-16)$, and $3 \mathrm{~mm}(17-20)$. 
the Santa Cruz Formation, S. osbornianus Ameghino, 1894 is the largest and the most abundant, whereas the type species, S. angustus, is less common. Scleromys is characterized by high-crowned molariforms with root formation and an occlusal pattern that consists in a long posterior labial flexid and an anterior lingual flexus. During the ontogeny, this genus displays a great amount of dental morphological change due to flexi/ids closure, fossette/ids disappearance, and changes in molar size and outline. For this reason, isolated teeth are difficult to assign to a species.

In the RSC the genus is not abundant, but Scleromys sp. was recorded both in BB and SBB (Tab. 2; Appendix 1).

\section{DISCUSSION}

\section{Caviomorph assemblages of the Río Santa Cruz localities}

In this contribution, a revision of the rodent fauna recorded in the localities of the RSC is presented (Tab. 1). The three fossil localities (BB, SBB, and $\mathrm{YH}$; Appendix 1) represent different age ranges, and only the upper part of BB overlaps with the lowest part of SBB (Cuitiño et al. 2016, 2019). Not all the Santacrucian caviomorphs were found in all these localities (see above). SBB is the most fossiliferous locality with 557 specimens $(72.5 \%$ of the fossil caviomorphs; ECA $n=179, E C A 2 n=272$, and EET $n=106$ ). In BB we found 208 specimens ( $27 \%$; EAG $n=124$, ESL $n=84$ ) and in $\mathrm{YH}$ only three caviomorphs $(0.4 \%)$ were recorded, making it the least fossiliferous locality (Appendix 1).

Octodontoidea. Octodontoids are the richest taxonomically and morphologically diverse group in the RSC with nine genera and 16 species (Appendix 1). This group is represented by low-crowned taxa. Some have low crowns with slightly terraced cheek teeth (e.g., Dudumus sp. nov.? and Acarechimys). Others have slightly higher crowns (e.g., Prospaniomys sp. nov.?, Acaremys). Still others have much higher crowns and planar occlusal surfaces (e.g., Sciamys, Stichomys, Spaniomys). The most abundant taxa are Spaniomys, Stichomys, Sciamys, and Acarechimys, all of them broadly represented in all the localities of the RSC (see results above; Appendix 1). Within acaremyids we note the first record at RSC of Sciamys latidens from (ECA2, SBB; Appendix 1). It differs from the remaining Santacrucian Sciamys species in having a p4 with a molarized posterior portion (presence of hypolophid; Fig. 2.21). This species was previ- ously known only by its holotype recorded at Killik Aike, near Río Gallegos, Province of Santa Cruz (Scott, 1905; Fig. 1). We also identify two new brachydont taxa (Prospaniomys sp. nov.? and Dudumus sp. nov.?). Prospaniomys sp. nov.? was recorded in ESL from BB and in ECA2 from SBB (Tab. 2; Appendix 1). In turn, Dudumus sp. nov.? was recorded in ECA2 (SBB). These records extend the biochron of both genera from the Colhuehuapian to the Santacrucian, as well as their geographic distributions (provinces of Chubut and Santa (ruz). Additionally, other brachydont specimens found in ESL (BB) could represent new taxa (e.g., MPM-PV 20184, MPM-PV 20205; Appendix 1). These specimens are important because low-crowned octodontoids dominated older caviomorph assemblages of Patagonia (Vucetich et al., 2010; Kramarz, 2004) and, until now, they were scarce in the Santa Cruz Formation -represented only by Acarechimys; Arnal et al. (2017)-. Thus, these new records expand the number of brachydont octodontoids for the Santacrucian.

Erethizontidae. Erethizontids have the least specific richness and abundance in the RSC. Within the new sample only 22 specimens are identified as Steiromys detentus (Fig. 3.23), S. duplicatus, and Steiromys sp. They have been found in BB (in EAG) and in SBB (in ECA, ECA2, and EET) (Appendix 1). This low abundance is in accordance with previous works (Ameghino, 1887a, 1889; Scott, 1905; Candela, 2000), in which Steiromys is the only recognized Santacrucian genus. Scott (1905) described Steiromys intermedius, another species from Guer Aike Department, Province of Santa Cruz (Fig. 1), that is not recorded in the RSC localities. As with octodontoids, the abundance of erethizontoids in the Santacrucian late Early-Middle Miocene greatly contrasts with that of the Colhuehuapian Early Miocene, where they are represented by four genera and several species (Vucetich et al., 2015). Neither erethizontids nor octodontoids show any biostratigraphic zonation within the RSC localities.

Cavioidea. Unlike the above mentioned caviomorph clades, cavioids and chinchilloids have interestingly different distribution and taxonomic abundance in the different RSC localities. Within cavioids the derived euhypsodont Schistomys is present in SBB (ECA2 and EET) but absent in $\mathrm{BB}$ and $\mathrm{YH}$. Phanomys and Eocardia are present in BB and in SBB 
(Tab. 2; Appendix 1), but they differ in their generic distribution. On the one hand, the primitive protohypsodont Phanomys is more abundant in BB, in which it is represented by 17 specimens -EAG $(n=16)$ and ESL $(n=1)-$, while in SBB only by 5 specimens -ECA $(n=1)$ and ECA2 $(n=4)-$. On the other hand, the derived euhypsodont Eocardia is much more abundant in SBB $(n=65)$ than in BB $(n=36$; Appendix 1$)$. Although biostratigraphic information generally is based on presence/absence of taxa in each locality, we interpret that the differences in abundance of Phanomys and Schistomys observed in BB and SBB are related to a taxonomic replacement of both taxa. The euhypsodont Eocardia was present in both localities, but became much more abundant in SBB.

Neoreomys australis is the most abundant cavioid represented by 131 specimens found in the three localities of the

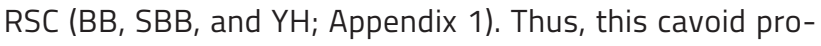
vides no biostratigraphic information.

Chinchilloidea. Within chinchilloids Perimys is present in BB $(n=21)$ and in SBB $(n=35)$. Nevertheless, between both localities the species distribution is different. In SBB the largest species, Perimys onustus, is clearly dominant with respect to the small and medium sized species of Perimys (P. erutus, $P$. incavatus, and Perimys sp.; Appendix 1), while in $\mathrm{BB} P$. onustus is represented by a single specimen. In this regard, we note the first RSC record of the small species Perimys incavatus in BB (EAG). P. incavatus was previously recorded in the Colhuehuapian (Early Miocene) of the Province of Chubut (Vucetich et al., 2010) and in the Santacrucian (Early-Middle Miocene) of southern Chile (Bostelmann et al., 2013). A different generic and specific distribution is observed for the derived euhypsodont Prolagostomus and Pliolagostomus. They are the most abundant chinchilloids in SBB $(n=176)$, while they are represented by only two specimens of Prolagostomus sp. in BB (Appendix 1). Scleromys is represented in BB and SBB by 12 specimens assigned to Scleromys sp. (Appendix 1).

Caviomorphs of other Santacrucian localities are poorly known. Ameghino (1891a,b, 1894) described new species of those Santacrucian genera described in $1887 \mathrm{a}, \mathrm{b}$ and 1889. But unfortunately, precise geographic and stratigraphic information is uncertain (Fernicola et al., 2014). Scott (1905) studied several caviomorphs from the Santa Cruz Formation recovered from the cliffs of RSC and coastal localities of the east of the Province of Santa Cruz (Killik Aike, 10 miles south of Coy inlet; Marshall, 1976; Vizcaíno et al., 2012b; Fig. 1). Except for a few species, all of them belong to the genera recovered previously in the RSC cliffs (i.e., Neoreomys, Phanomys, Schistomys, Eocardia, Stichomys, Spaniomys, Steiromys, Sciamys, Acaremys, Acarechimys, and Scleromys).

In summary, we observed a reduction in the taxonomic diversity but an increased in the morphological disparity of the rodent assemblage from the RSC (Tab. 1 and discussion above) than previously known (Ameghino, 1887a,b, 1889, 1891; Scott, 1905; Tab. 1). This work is the first comprehensive attempt in revising the Santacrucian caviomorphs. Similar systematic revisions should be approached with the caviomorph materials collected in other Santacrucian localities, in order to better understand the Santacrucian caviomorph assemblage as a whole.

\section{GENERAL EVOLUTIONARY ASPECTS}

Santacrucian rodents show significant changes compared with those of older Colhuehuapian and "Pinturan" SALMAs (Kramarz, 2004, 2006a,b; Kramarz and Bellosi, 2005; Vucetich et al. 2010; Pérez and Pol, 2012; Arnal and Vucetich, 2015a). Several lineages experienced a progressive increase in hypsodonty (e.g., octodontoids with Sciamys, Stichomys, Spaniomys) or even acquired euhypsodonty for the first time (e.g., cavioids, chinchillids). Those rodents with more generalized dental patterns (e.g., Steiromys) became less common. Within Cavioidea, the acquisition of hypsodonty is first seen during the Santacrucian SALMA (Pérez and Pol, 2012), but the increase in dental crown height is already recorded in previous ages (e.g., Luantus in the Colhuehuapian and "Pinturan"; Chubutomys Wood and Patterson, 1959 in the Deseadan SALMA), unlike what is observed in octodontoids, which show increased crown height for the first time in the Santacrucian. In the RSC localities, meso-, proto, and euhypsodont taxa coexisted for some time during the Santacrucian (see previous section). Until now mesodont forms that would eventually give origin to the modern Dasyproctidae on the one hand and euhypsodont forms that would originate the Family Caviidae on the other hand, were recorded only in younger ages (e.g., "Colloncuran", Laventan, Mayoan, early Late Miocene). Interestingly, a similar trend 
occurs within Chinchilloidea. During the Santacrucian, Perimys is the most abundant chinchilloid in BB and had the greatest specific richness. In SBB this taxonomic richness decreased (represented mostly by $P$. onustus); the record from SBB marks the last appearance of the genus. This taxonomic decrease is observed together with the rise in the abundance of specimens of the derived lagostomines Pliolagostomus and Prolagostomus. Noteworthy, one Perimys species in SBB coexisted, which is larger than the abovementioned lagostomines. This may be related to the biology of these taxa, probably $P$. onustus not competing for ecological requirements with the other chinchilloids.

Within octodontoids, the record of Dudumus sp. nov.? and Prospaniomys sp. nov.? expand the biochron and geographic distribution of these genera. Both taxa and Acarechimys are the only brachydont octodontoids in the RSC and are also recorded in older Colhuehuapian beds. Nevertheless, they differ in that Dudumus and Prospaniomys were abundant in older beds and are represented by only four specimens in the RSC, while Acarechimys is much more abundant in the Santacrucian. In addition, Acarechimys and Sciamys are the only octodontoids recorded in younger Middle Miocene beds (Arnal and Pérez, 2013; Arnal et al., 2017). These younger Acarechimys maintained the brachydont cheek tooth structure, and are not recorded in Patagonia but in middle latitudes of the continent (Quebrada Honda, Bolivia; see Arnal et al., 2017). This geographic distribution was proposed to be the result of a migration event (from Patagonia to lower latitudes regions) induced by the marked aridization and cooling of higher latitudes of South America after the Early Miocene (Arnal et al., 2017). On the other hand, the last record of Sciamys is that of Sciamys petisensis, found in the locality of El Petiso, Province of Chubut (Arnal and Pérez, 2013). The fossil-bearing bed of El Petiso is estimated to be of Middle-Late Miocene Age. Sciamys petisensis is higher-crowned than its Santacrucian relatives. In fact, it is the highest-crowned and last recorded acaremyid (Arnal and Pérez, 2013). This survival would be the result not of a migration like Acarechimys, but of increasing hypsodonty in order to counteract the aridization of these latitudes. Erethizontids became scarce in Patagonia by the Santacrucian, being since then recorded only in lower lati- tudes (e.g., Bolivia, Colombia).

In addition to this turnover in teeth morphology, Santacrucian rodents have different sizes: they were large (Neoreomys, Perimys onustus), medium-sized (Scleromys, Steiromys, Eocardia, and the remaining Perimys species) and small (octodontoids). This diversity reflects a wide range of habits, suggesting they had acquired broad paleobiologic adaptations by the Early-Middle Miocene (Candela et al., 2012; Muñoz et al., 2019). This, in turn, is related to the environment in which they lived. Recent works proposed more humid and forested paleoenvironments for the Santa Cruz Formation (Kay et al., 2008, 2012; Brea et al., 2012; Rasia, 2016) than historically proposed (Pascual et al., 1996; Vucetich et al., 2015). Evidently, these varied landscape scenarios (that resulted from considerable climatic changes) permitted the evolution and diversification of the Santacrucian caviomorphs. Paleobiological aspects deserve further detailed analyses which are beyond the scope of this systematic study.

\section{ACKNOWLEDGMENTS}

We are very grateful with J.C. Fernicola (MACN), S.F. Vizcaíno (MLP), M.S. Bargo (MLP), and R.F. Kay (Duke University, USA) for trusting us and providing the Santacrucian caviomorph fossils, as well as for the invitation to participate in this volume. We especially want to thank and express our admiration to M.G. Vucetich (MLP), who leaded us in this awesome world of fossil South American rodents. We appreciate the assistance of the Curators of the MEF, MACN, $M L P$, and MPM for providing the specimens under their care for study. B. Pianzola (MLP) and Sr. C. Alejandro for the caviomorph pictures. To M. Ubilla, L. Kerber, and the editors of this Special Volume for their valuable comments that greatly helped to improve this work. This paper was partly funded by PICT-2014-2734; PICT2010-2613; PICT-2012-1483; PICT-2016-0566. Field work was supported by the following grants: PIP-CONICET 00781 (To J.C. Fernicola), UNLP 11/N867, PICT 2013-0389 (to S.F. Vizcaíno) and 2017-1081 (to M.S. Bargo), National Science Foundation grants 0851272 and 1348259, and National Geographic Society 9167-12 (to R.F. Kay).

\section{REFERENCES}

Álvarez, A., Pérez, S.I., and Verzi, D.H. 2011. Ecological and phylogenetic influence on mandible shape variation of South American caviomorph rodents (Rodentia, Hystricomorpha). Biological Journal of the Linnean Society 102: 828-837.

Ameghino, F. 1887a. Enumeración sistemática de las especies de mamíferos fósiles coleccionadas por Carlos Ameghino en los terrenos eocenos de la Patagonia austral. Boletín del Museo de La Plata 1: 1-26.

Ameghino, F. 1887b. Observaciones generales sobre el orden de mamíferos extinguidos sudamericanos llamados toxodontes (Toxodontia) y sinopsis de los géneros y especies hasta ahora 
conocidos. Anales del Museo de La Plata (Entrega especial, 1936): 1-66.

Ameghino, F. 1889. Contribución al conocimiento de los mamíferos fósiles de la República Argentina. Actas de la Academia Nacional de Ciencias en Córdoba 6: 1-1027.

Ameghino, F. 1891a. Caracteres diagnósticos de cincuenta especies nuevas de mamíferos fósiles argentinos. Revista Argentina de Historia Natural 1: 129-167.

Ameghino, F. 1891b. Nuevos restos de mamíferos fósiles descubiertos por Cárlos Ameghino en el Eoceno inferior de la Patagonia austral. Especies nuevas, adiciones y correcciones. Revista Argentina de Historia Natural 1: 289-328.

Ameghino, F. 1894. Enumération synoptique des espéces des mammiferes fósiles des formations éocenes de Patagonie. Boletín de la Academia Nacional de Ciencias de Córdoba 13: 259-452.

Ameghino, F. 1897. Mammifères Crétacés de l'Argentine. Deuxième contribution à la connaissance de la faune mammalogique des couches à Pyrotherium. Boletín del Instituto Geográfico Argentino 18: 460-521.

Ameghino, F. 1902. Première Contribution à la connaissance de la faune mammalogique des couches à Colpodon. Boletín de la Academia Nacional de Ciencias en Córdoba 17: 71-138.

Ameghino, F. 1906. Les Formations sedimentaires du Crétacé supérieur et du Tertiaire de Patagonie. Anales del Museo Nacional de Buenos Aires 8: 1-568.

Arnal, M. 2012. [Sistemática, filogenia e historia evolutiva de roedores Octodontoidea (Caviomorpha, Hystricognathi) del Oligoceno tardioMioceno medio vinculados al origen de la familia Octodontidae. Tesis doctoral, Facultad de Ciencias Naturales y Museo, Universidad Nacional de La Plata, La Plata, 317 p. Unpublished.].

Arnal, M., Kramarz, A.G., Vucetich, M.G., and Vieytes, C.E. 2014. A new Early Miocene octodontoid rodent (Hystricognathi, Caviomorpha) from Patagonia (Argentina) and a reassessment of the early evolution of Octodontoidea. Journal of Vertebrate Paleontology 34: 397-406.

Arnal, M., and Pérez, M.E. 2013. A new acaremyid rodent (Hystricognathi, Octodontoidea) from the Middle Miocene of Patagonia (South America) and considerations on the early evolution of Octodontoidea. Zootaxa 3616: 119-134.

Arnal, M., and Vucetich, M.G. 2015a. Main radiation events in PanOctodontoidea (Rodentia, Caviomorpha). Zoological Journal of the Linnean Society 175: 587-606.

Arnal, M., and Vucetich, M.G. 2015b. Revision of the fossil rodent Acaremys Ameghino, 1887 (Hystricognathi, Octodontoidea, Acaremyidae) from the Miocene of Patagonia (Argentina) and the description of a new acaremyid. Historical Biology 27: 42-59.

Arnal, M., Vucetich, M.G., Croft, D.A., Bargo, M.S., Fernicola, J.C., and Vizcaíno, S.F. 2017. Systematic revision and evolutionary history of Acarechimys Patterson in Kraglievich, 1965 (Rodentia, Caviomorpha, Octodontoidea). Ameghiniana 54: 307-330.

Bostelmann, J.E., Le Roux, J.P., Vásquez, A., Gutiérrez, N.M., Oyarzun, J.L., Carreño, C., Torres, T., Otero, R., Llanos, A., Fanning, C.M., and Herve, F. 2013. Burdigalian deposits of the Santa Cruz Formation in the Sierra Baguales, Austral (Magallanes) Basin: Age, depositional environment and vertebrate fossils. Andean Geology 40: 458-489.

Brandoni, D., González Ruiz, L., and Bucher, J. 2019. Evolutive implications of Megathericulus patagonicus (Xenarthra, Megatheriinae) from the Miocene of Patagonia Argentina. Journal of Mammalian Evolution. doi: 10.1007/s10914-019-09469-6

Brandoni, D., González Ruiz, L., Reato, A., and Martin, G. 2017. Chro- nological implications of the nothrotheriid 'Xyophorus' (Mammalia, Xenarthra) from the Collón Curá Formation (Miocene of Patagonia, Argentina). Historical Biology. doi: https://doi.org/10.1080/ 08912963.2017 .1398748

Brea, M., Zucol, A.F., Iglesias, A. 2012. Fossil plant studies from late Early Miocene of the Santa Cruz Formation: paleoecology and paleoclimatology at the passive margin of Patagonia, Argetina. In: S.F. Vizcaíno, R.F. Kay, and M.S. Bargo (Eds.), Early Miocene Paleobiology in Patagonia. Cambridge University Press, Cambridge, p. $104-128$.

Busker, F., Pérez, M.E., Krause, J.M., and Vucetich, M.G. 2018. First record of Banderomys leanzai Kramarz, 2005 (Rodentia, Caviomorpha) in Chubut Province, Patagonia (Argentina). Revista del Museo Argentino de Ciencias Naturales 19: 121-129.

Candela, A.M. 2000. [Los Erethizontidae (Rodentia, Hystricognathi) fósiles de Argentina. Sistemática e historia evolutiva y biogeografía. Tesis doctoral, Facultad de Ciencias Naturales y Museo, Universidad Nacional de La Plata, La Plata, 352 p. Unpublished.].

Candela, A.M., and Nasif, N.L. 2006. Systematics and biogeographic significance of Drytomomys typicus (Scalabrini in Ameghino, 1889) nov. comb., a Miocene Dinomyidae (Rodentia, Hystricognathi) from northeast of Argentina. Neues Jahrbuch für Geologie und Paläontologie 3: 165-181.

Candela, A.M., Rasia, L.L., and Pérez, M.E. 2012. Paleobiology of Santacrucian caviomorph rodents: a morphofunctional approach. In: S.F. Vizcaíno, R.F. Kay, and M.S. Bargo (Eds.), Early Miocene Paleobiology in Patagonia: High-Latitude Paleocommunities of the Santa Cruz Formation. Cambridge University Press, Cambridge, p. 287-305.

Croft, D.A., Flynn, J.J., and Wyss, A.R. 2004. Notoungulata and Litopterna of the Early Miocene Chucal Fauna, northern Chile. Fieldiana: Geology (New Series) 50: 1-52.

Cuitiño, J.I., Fernicola, J.C., Kohn, M.J., Trayler, R., Naipauer, M., Bargo, M.S, Kay, R.F., and Vizcaíno, S.F. 2016. U-Pb geochronology of the Santa Cruz Formation (Early Miocene) at the Río Bote and Río Santa Cruz (southernmost Patagonia, Argentina): implications for the correlation of fossil vertebrate localities. Journal of South American Earth Sciences 70: 198-210.

Cuitiño, J.I. Fernicola, J.C., Raigemborn, M.S., and Krapovickas, V. 2019. Stratigraphy and depositional environments of the Santa Cruz Formation (Early-Middle Miocene) along the Río Santa Cruz, Southern Patagonia, Argentina. In: J.C. Fernicola, M.S. Bargo, S.F. Vizcaíno, and R.F. Kay (Eds.), Early-Middle Miocene Paleontology in the Río Santa Cruz, Southern Patagonia, Argentina. 130 years since Ameghino, 1887. Publicación Electrónica de la Asociación Paleontológica Argentina 19: 14-33.

Fernicola, J.C., Bargo, M.S., Vizcaíno, S.F., and Kay, R.F. 2019. Historical background for a revision of the paleontology of the Santa Cruz Formation (Early-Middle Miocene) along the Río Santa Cruz, Patagonia, Argentina. In: J.C. Fernicola, M.S. Bargo, S.F. Vizcaíno, and R.F. Kay (Eds.), Early-Middle Miocene Paleontology in the Rio Santa Cruz, Southern Patagonia, Argentina. 130 years since Ameghino, 1887. Publicación Electrónica de la Asociación Paleontológica Argentina 19: 1-13.

Fernicola, J.C., Cuitiño, J.I., Vizcaíno, S.F., Bargo, M.S., and Kay, R.F. 2014. Fossil localities of the Santa Cruz Formation (Early Miocene, Patagonia, Argentina) prospected by Carlos Ameghino in 1887 revisited and the location of the Notohippidian. Journal of South American Earth Sciences 52: 94-107.

Fields, R.W. 1957. Hystricomorph rodents from the Late Miocene of Colombia, South America. University of California Publications in Geological Sciences 32: 273-404. 
Flynn, J.J., Charrier, R., Croft, D.A., Gans, Ph.B., Herriott, T.M., Wertheim, J.A., and Wyss, A.R. 2008. Chronologic implications of new Miocene mammals from the Cura-Mallin and Trapa Trapa Formations, Laguna del Laja area, south central Chile. Journal of South American Earth Sciences 26: 412-423.

Flynn, J.J., Novacek, M.J., Dodson, H.E., Frassinetti, D., McKenna, M.C., Norell, M.A., Sears, K.E., Swisher III, C.C., and Wyss, A.R. 2002. A new fossil assemblage from the southern Chilean Andes: implications for geology, geochronology, and tectonics. Journal of South American Earth Sciences 15: 285-302.

Frailey, C.D., and Campbell, K.E. Jr. 2004. Paleogene Rodents from Amazonian Peru: The Santa Rosa Local Fauna. In: K.E.Campbell (Ed.), The Paleogene Mammalian Fauna of Santa Rosa, Amazonian Peru. Natural History Museum of Los Angeles County, Sciences Series 40, Los Angeles, p. 71-130.

González Ruiz, L., Góis Lima, F., Ciancio, M., and Scillato-Yané, G. 2013. Los Peltephilidae (Mammalia, Xenarthra) de la Formación Collón Curá (Colloncurense, Mioceno medio), Argentina. Revista Brasileira de Paleontologia 16: 319-330.

González Ruiz, L., Reato, A., Cano, M., and Martínez, O. 2017. Old and new specimens of a poorly known glyptodont from the Miocene of Patagonia and their biochronological implications. Acta Palaeontologica Polonica 62: 181-194.

Gray, J.E. 1843. List of the specimens of Mammalia in the Collection of the British Museum. British Museum, London, 216 p.

Illiger, J.K.W. 1811. Prodomus systematics mammalium et avium additis terminis zoographicis utriusque classis, eorumque versione germanica. Berolini, Berlin, 302 p.

Kay, R.F., Vizcaíno, S.F., Bargo, M.S., Perry, J.M.G., Prevosti, F., and Fernicola, J.C. 2008. Two new fossil vertebrate localities in the Santa Cruz Formation (late early-early Middle Miocene, Argentina), 51 South latitude. Journal of South American Earth Sciences 25: 87-195.

Kay, R.F., Vizcaíno, S.F., and Bargo, M.S. 2012. A review of the paleoenvironment and paleoecology of the Miocene Santa Cruz Formation. In: S.F. Vizcaíno, R.F. Kay, and M.S. Bargo (Eds.), Early Miocene Paleobiology in Patagonia. Cambridge University Press, Cambridge, p. 331-365.

Kraglievich, J.L. 1965. Speciation phyletique dans les rongeurs fossiles du genre Eumysops Ameghino (Echimyidae, Heteropsomyinae). Extrait de Mammalia 29: 258-267.

Kramarz, A.G. 2001. Un nuevo roedor Adelphomyinae (Hystricognathi, Echimyidae) del Mioceno medio-inferior de Patagonia, Argentina. Ameghiniana 38: 163-168.

Kramarz, A.G. 2002. Roedores chinchilloideos (Hystricognathi) de la Formación Pinturas, Mioceno temprano-medio de la provincia de Santa Cruz, Argentina. Revista del Museo Argentino de Ciencias Naturales 4: 167-180.

Kramarz, A.G. 2004. Octodontids and erethizontoids (Rodentia, Hystricognathi) from the Pinturas Formation, Early-Middle Miocene of Patagonia, Argentina. Ameghiniana 41: 199-216.

Kramarz, A.G. 2006a. Eocardiids (Rodentia, Hystricognathi) from the Pinturas Formation, late Early Miocene of Patagonia, Argentina. Journal of Vertebrate Paleontology 26: 770-778.

Kramarz A.G. 2006b. Neoreomys and Scleromys (Rodentia, Hystricognathi) from the Pinturas Formation, late Early Miocene of Patagonia, Argentina. Revista del Museo Argentino de Ciencias Naturales 8: 53-62.

Kramarz, A.G., and Bellosi, E.S. 2005. Hystricognath rodents from the Pinturas Formation, Early-Middle Miocene of Patagonia, biostratigraphic and paleoenviromental implications. Journal of
South American Earth Sciences 18: 199-212.

Kramarz, A.G., Vucetich, M.G., and Arnal, M. 2013. A new Early Miocene chinchilloid hystricognath rodent. An approach to the understanding of the early chinchillid dental evolution. Journal of Mammalian Evolution 20: 249-261.

Kramarz, A.G., Vucetich, M.G., Carlini, A.A., Ciancio, M.R., Abello, M.A., Deschamps, C.M., and Gelfo, J.N. 2010. A new mammal fauna at the top of the Gran Barranca sequence and its biochronological significance. In: R.H. Madden, A.A. Carlini, M.G. Vucetich, and R.F. Kay (Eds.), The Paleontology of Gran Barranca, evolution and environmental change through the middle Cenozoic of Patagonia. Cambridge University, Cambridge, p. 264-277.

López, G.M., Vucetich, M.G., Carlini, A.A., Bond, M., Pérez, M.E., Ciancio, M.R., Pérez, D.J., Arnal, M., and Olivares, A.I. 2011. New Miocene mammal assemblage from Neogene Manantiales Basin, Cordillera Frontal, San Juan, Argentina. In: J.A. Salfity, and R.A. Marquillas (Eds.), Cenozoic Geology of the Central Andes of Argentina. SCS Publisher, Salta, p. 211-226.

Madden, R.H. 2015. Hypsodonty in Mammals: evolution, geomorphology, and the role of earth surface processes. Cambridge University Press, Cambridge, $423 \mathrm{p}$.

Marshall, L.G. 1976. Fossil localities for Santacrucian (Early Miocene) mammals, Santa Cruz Province, Southern Patagonia, Argentina. Journal of Paleontology 50: 1129-1142.

Marshall, L.G., and Salinas, P. 1990. Vertebrados continentales del Mioceno inferior de Magallanes, Chile. Revista Geológica de Chile 17: 57-87.

Muñoz, N.A., Toledo, N., Candela, A.M., and Vizcaíno, S.F. 2019. Functional morphology of the forelimb of Early Miocene caviomorph rodents from Patagonia. Lethaia 52: 91-106.

Ortiz-Jaureguizar, E., and Cladera, G.A. 2006. Paleoenvironmental evolution of southern South America during the Cenozoic. Journal of Arid Environments 66: 498-532.

Pascual, R., Ortiz-Jaureguizar, E., and Prado, J.L. 1996. Land mammals: paradigm of Cenozoic South American geobiotic evolution. In: G. Arratia (Ed.), Contribution of Southern South America to Vertebrate Paleontology. Müncher Geowissenschaftliche Abhandlungen, Munich, p. 265-319.

Patterson, B., and Pascual, R. 1968. New echimyids rodents from the Oligocene of Patagonia and a synopsis of the Family. Breviora 301: 1-14.

Patterson, B., and Wood, A.E. 1982. Rodents from the Deseadan Oligocene of Bolivia and the Relationships of the Caviomorpha. Bulletin of the Museum of Comparative Zoology 149: 371-543.

Patton, J.L., Pardiñas, U.F.J., and D'Elía, G. 2015. Mammals of South America, vol. 2, Rodents. University of Chicago Press, Chicago, $1336 \mathrm{p}$.

Pérez, M.E. 2010a. A new rodent (Cavioidea, Hystricognathi) from the Middle Miocene of Patagonia, mandibular homologies, and the origin of the crown group Cavioidea sensu stricto. Journal of Vertebrate Paleontology 30: 1848-1859.

Pérez, M.E. 2010b. [Sistemática, ecología y bioestratigrafía de Eocardiidae (Rodentia, Hystricognathi, Cavioidea) del Mioceno temprano y medio de Patagonia. Tesis Doctoral, Facultad de Ciencias Naturales y Museo, Universidad Nacional de La Plata, La Plata, 385 p. Unpublished.].

Pérez, M.E., and Pol, D. 2012. Major Radiations in the Evolution of Caviid Rodents: Reconciling Fossils, Ghost Lineages, and Relaxed Molecular Clocks. PLOS ONE doi: 10.1371/journal.pone. 0048380

Pérez, M.E., and Vucetich, M.G. 2012. A revision of the fossil genus 
Phanomys Ameghino, 1887 (Rodentia, Hystricognathi, Cavioidea) from the early Miocene of Patagonia (Argentina) and the acquisition of euhypsodonty in Cavioidea sensu stricto. Paläontologische Zeitschrift 86: 187-204.

Pérez, M.E., Vucetich, M.G., and Kramarz, A.G. 2010. The first Eocardiidae (Rodentia) in the Colhuehuapian (early Miocene) of Bryn Gwyn (Northern Chubut, Argentina) and the early evolution of the peculiar cavioid rodents. Journal of Vertebrate Paleontology 30: 528-534.

Rasia, L.L. 2016. [Los Chinchillidae (Rodentia, Caviomorpha) fósiles de la República Argentina: sistemática, historia evolutiva y biogeográfica, significado bioestratigráfico y paleoambiental. Tesis Doctoral, Facultad de Ciencias Naturales y Museo, Universidad Nacional de La Plata, La Plata, 246 p. Unpublished.].

Rasia, L.L., and Candela, A.M. 2019. Prolagostomus amplus Ameghino, 1894 is a junior synonym of the Patagonia rodent Pliolagostomus notatus Ameghino, 1887 (Chinchillidae; early Miocene, Santa Cruz Formation). Ameghiniana 56: 72-77.

Scott, W.B. 1905. Mammalia of the Santa Cruz beds. Part III, Glires. In: Reports of the Princeton University Expeditions to Patagonia 1896-1899. Princeton University Press, New Jersey, 348-487.

Tauber, A.A. 1997. Los vertebrados de la Formación Santa Cruz (Mioceno inferior-medio) en el extremo sureste de la Patagonia y su significado paleoecológico. Ameghiniana 34: 517-529.

Thomas, 0. 1903. Notes in South American monkeys, bats, carnivores, and rodents, with descriptions of new species. Annals and Magazine of Natural History 12: 455-464.

Upham, N.S., and Patterson, B.D. 2015. Phylogeny and evolution of caviomorph rodents: a complete timetree for living genera. In: A.I. Vasallo, and D. Antenucci (Eds.), Biology of Caviomorph Rodents: diversity and evolution. SAREM Series A, Mammalogical Research (Investigaciones Mastozoológicas), Ciudad Autónoma de Buenos Aires, p. 63-120.

Vasallo, A.I., and Antenucci, D. 2015. Biology of Caviomorph rodents: Diversity and Evolution. SAREM Series A, Mammalogical Research (Investigaciones Mastozoológicas), Ciudad Autónoma de Buenos Aires, $329 \mathrm{p}$.

Vera, B., González Ruiz, L., Novo, N., Martin, G., Reato, A., and Tejedor, M.F. 2018. The Interatheriinae (Mammalia, Notoungulata) of the Friasian sensu stricto and Mayoan (middle to late Miocene), and the fossils from Cerro Zeballos, Patagonia, Argentina. Journal of Systematic Palaeontology. doi: 10.1080/14772019. 2018.1511387

Vera, B., Reguero, M.A., and González Ruiz, L. 2017. The Interatheriinae (Notoungulata) from the Collón Curá Formation (middle Miocene), Argentina. Acta Palaeontologica Polonica 62: 845-863.

Verzi, D.H., Olivares, A.I., and Morgan, C.C. 2014. Phylogeny, evolutionary patterns and timescale of South American octodontoid rodents. The importance of recognizing morphological differentiation in the fossil record. Acta Palaeontologica Polonica 757-769.

Vizcaíno, S.F., Kay, R.F., and Bargo, M.S. 2012a. Early Miocene Paleobiology in Patagonia: High-latitude Paleocommunities of the Santa Cruz Formation. Cambridge University Press, Cambridge, 370 p.
Vizcaíno, S.F., Kay, R.F., and Bargo, M.S. 2012b. Background for a paleoecological study of the Santa Cruz Formation (late Early Miocene) on the Atlantic coast of Patagonia. In: S.F. Vizcaíno, R.F. Kay, and M.S. Bargo (Eds.), Early Miocene Paleobiology in Patagonia. Cambridge University Press, Cambridge, p. 1-22.

Vucetich, M.G., Arnal, M., Deschamps, C.M., Pérez, M.E., and Vieytes, E.C. 2015. A brief history of caviomorph rodents as told by the fossil record. In: A.I. Vasallo, and D. Antenucci (Eds.), Biology of Caviomorph Rodents: diversity and evolution. SAREM Series A, Mammalogical Research (Investigaciones Mastozoológicas), Ciudad Autónoma de Buenos Aires, p. 11-62.

Vucetich, M.G., Dozo, M.T., Arnal, M., and Pérez, M.E. 2014. New rodents (Mammalia) from the Late Oligocene of Cabeza Blanca (Chubut) and the first rodent radiation in Patagonia. Historical Biology: An International Journal of Paleobiology 27: 236-257.

Vucetich, M.G., and Kramarz, A.G. 2003. New Miocene rodents of Patagonia (Argentina) and their bearing in the early radiation of the octodontiform octodontoids. Journal of Vertebrate Paleontology 23: 435-444.

Vucetich, M.G., Kramarz, A.G., and Candela, A.M. 2010. Colhuehuapian rodents from Gran Barranca and other Patagonian localities: the state of the art. In: R.H. Madden, A.A. Carlini, M.G. Vucetich, and R.F. Kay (Eds.), The Paleontology of Gran Barranca: Evolution and Environmental Change through the Middle Cenozoic of Patagonia. University of Cambridge Press, Cambridge, p. 206-219.

Vucetich, M.G., and Verzi, D.H. 1996. A peculiar octodontoid (Rodentia, Caviomorpha) with terraced molars from the Lower Miocene of Patagonia (Argentina). Journal of Vertebrate Paleontology 16: 297-302.

Wood, A.E. 1949. A new Oligocene rodent genus from Patagonia. American Museum Novitates 1435: 1-54.

Wood, A.E. 1955. A revised classification of the rodents. Journal of Mammalogy 36: 165-187.

Wood, A.E., and Patterson, B. 1959. The rodents of the Deseadan Oligocene of Patagonia and the beginnings of South American rodent evolution. Bulletin of the Museum of Comparative Zoology 120: 281-428.

Zachos, J., Pagani, M., Sloan, L., Thomas, E., and Billups, K. 2001. Trends, rhytms, and aberrations in global climate $65 \mathrm{Ma}$ to present. Science 292: 686-693.

Doi: 10.5710/PEAPA.25.09.2019.299

Recibido: 22 de mayo 2019

Aceptado: 25 de septiembre 2019 
APPENDIX 1 - List of fossil caviomorph specimens from the Río Santa Cruz. In different shades of green: Barrancas Blancas (BB), Estancia Aguada Grande (EAG), and Estancia Santa Lucia (ESL); in different shades of blue: Segundas Barrancas Blancas (SBB), Estancia Cordón Alto (ECA), Estancia Cordón Alto2 (ECA2), and Estancia El Tordillo (EET); Orange: Yaten Huageno (YH) and Estancia El Refugio (EER)

\begin{tabular}{|c|c|c|c|c|}
\hline Locality & Estancia & Collection number & Systematic taxonomy & Material \\
\hline \multirow{46}{*}{$B B$} & \multirow{46}{*}{$\begin{array}{l}\text { Estancia } \\
\text { Aguada } \\
\text { Grande (EAG) }\end{array}$} & MPM-PV 20773 & Sciamys principalis & left mandible with $p 4-m 3$ \\
\hline & & MPM-PV 20036 & Phanomys mixtus & right $P 4$ \\
\hline & & MPM-PV 20037 & Phanomys mixtus & right $M 1$ or $M 2$ \\
\hline & & MPM-PV 20038 & Neoreomys australis & right $M 1$ or $M 2$ \\
\hline & & MPM-PV 20039 & Perimys $s p$. & isolated upper tooth \\
\hline & & MPM-PV 20040 & Spaniomys sp. & right upper molar \\
\hline & & MPM-PV 20041 & Spaniomys sp. & right upper molar \\
\hline & & MPM-PV 20042 & Spaniomys sp. & right upper molar \\
\hline & & MPM-PV 20043 & Acaremyidae & left lower molar \\
\hline & & MPM-PV 20044 & Sciamys? & left $p 4$ \\
\hline & & MPM-PV 20045 & Neoreomys australis & right maxilla with DP4-M3 \\
\hline & & MPM-PV 20046 & Neoreomys australis & left $M 1$ or $M 2$ \\
\hline & & MPM-PV 20047 & Neoreomys australis & right p4 \\
\hline & & MPM-PV 20048 & Phanomys mixtus & right M2-M3 \\
\hline & & MPM-PV 20049 & Perimys erutus & left $M 1$ or $M 2$ \\
\hline & & MPM-PV 20050 & "Eocardia" excavata? & left upper molar \\
\hline & & MPM-PV 20051 & "Eocardia" excavata? & left $m 1$ \\
\hline & & MPM-PV 20052 & "Eocardia" excavata? & right m3 \\
\hline & & MPM-PV 20053 & Eocardia montana & right mandibular fragment with $p 4-m 2$ \\
\hline & & MPM-PV 20054 & Eocardia $s p$ & left $m 3$ \\
\hline & & MPM-PV 20055 & Perimys/ Prolagostomus & right m3 \\
\hline & & MPM-PV 20056 & Neoreomys australis & right upper molar \\
\hline & & MPM-PV 20057 & Octodontoidea & edentulous left zygomatic fragment \\
\hline & & MPM-PV 20058 & Steiromys detentus & right upper molar \\
\hline & & MPM-PV 20059 & Acaremyidae & broken $\mathrm{P} 4$ \\
\hline & & MPM-PV 20060 & Spaniomys & right lower tooth broken \\
\hline & & MPM-PV 20061 & Neoreomys australis & right M1-M2 \\
\hline & & MPM-PV 20062 & Neoreomys australis & left $m 1$ or $m 2$ \\
\hline & & MPM-PV 20063 & Neoreomys australis & left M1 or M2 \\
\hline & & MPM-PV 20064 & Eocardia montana & left $p 4$ \\
\hline & & MPM-PV 20065 & Eocardia montana & right m1 \\
\hline & & MPM-PV 20066 & Eocardia montana & right $m 2$ \\
\hline & & MPM-PV 20067 & "Eocardia" excavata & left mandible with m1-m2 \\
\hline & & MPM-PV 20068 & Spaniomys sp. & right mandible with $m 1-m 2$ \\
\hline & & MPM-PV 20069 & Acarechimys minutissimus & right mandible with $m 1-m 2$ \\
\hline & & MPM-PV 20070 & Octodontoidea & lower incisor \\
\hline & & MPM-PV 20071 & Caviomorpha & lower incisor \\
\hline & & MPM-PV 20072 & Phanomys mixtus & left M3 \\
\hline & & MPM-PV 20073 & Phanomys mixtus & right M3 \\
\hline & & MPM-PV 20074 & Phanomys mixtus & right M1 \\
\hline & & MPM-PV 20075 & Phanomys mixtus & left M1 \\
\hline & & MPM-PV 20076 & Phanomys mixtus & right $M 2$ \\
\hline & & MPM-PV 20077 & Phanomys mixtus & left M2 \\
\hline & & MPM-PV 20078 & Phanomys mixtus & right $m 1$ or $m 2$ \\
\hline & & MPM-PV 20079 & Phanomys mixtus & left $m 1$ \\
\hline & & MPM-PV 20080 & Phanomys mixtus & left $m 1$ or $m 2$ \\
\hline
\end{tabular}


Appendix 1 - Continued

\begin{tabular}{|c|c|c|c|c|}
\hline Locality & Estancia & Collection number & Systematic taxonomy & Material \\
\hline & & MPM-PV 20081 & Spaniomys sp. & upper cheek teeth \\
\hline & & MPM-PV 20082 & Neoreomys australis & right $M 1$ or $M 2$ \\
\hline & & MPM-PV 20083 & Scleromys sp. & left $M 1$ or $M 2$ \\
\hline & & MPM-PV 20084 & Scleromys sp. & left M1 or M2 \\
\hline & & MPM-PV 20085 & Scleromys sp. & P4? \\
\hline & & MPM-PV 20086 & Steiromys duplicatus & left DP4 \\
\hline & & MPM-PV 20087 & Steiromys duplicatus & right $M 1$ or $M 2$ \\
\hline & & MPM-PV 20088 & Steiromys duplicatus & right $M 1$ or $M 2$ (broken) \\
\hline & & MPM-PV 20089 & Steiromys duplicatus & right M1 or M2 (broken) \\
\hline & & MPM-PV 20090 & Steiromys duplicatus & left $M 1$ or $M 2$ \\
\hline & & MPM-PV 20091 & Steiromys duplicatus & left $M 1$ or $M 2$ \\
\hline & & MPM-PV 20092 & Steiromys duplicatus & left M3 \\
\hline & & MPM-PV 20093 & Steiromys duplicatus & left dp4 \\
\hline & & MPM-PV 20094 & Steiromys duplicatus & left mandibular fragment with $\mathrm{m} 2$ \\
\hline & & MPM-PV 20095 & Steiromys duplicatus & left lower incisor \\
\hline & & MPM-PV 20096 & Steiromys $s p$. & 2 incisor fragments \\
\hline & & MPM-PV 20097 & Steiromys $s p$. & 2 broken teeth \\
\hline & & MPM-PV 20098 & Scleromys $s p$. & left upper molar \\
\hline & & MPM-PV 20099 & Scleromys $s p$. & left upper molar \\
\hline & & MPM-PV 20100 & Rodentia? & 1 phalanx \\
\hline & & MPM-PV 20101 & Rodentia? & distal left humerous \\
\hline & & MPM-PV 20102 & Rodentia? & right astragalus \\
\hline & & MPM-PV 20103 & Stichomys sp. & left maxillary fragment with DP4-M1 \\
\hline & & MPM-PV 20104 & Stichomys $s p$. & right $m 1$ or $m 2$ \\
\hline & & MPM-PV 20105 & Octodontoidea & left lower molar broken \\
\hline & & MPM-PV 20106 & Stichomys $s p$. & right m3 \\
\hline & & MPM-PV 20107 & Steiromys duplicatus? & right $D P 4 ?$ \\
\hline & & MPM-PV 20108 & Perimys erutus & right M3 \\
\hline & & MPM-PV 20109 & Eocardia montana & right $m 1$ or $m 2$ \\
\hline & & MPM-PV 20110 & Eocardia montana & right $m 1$ or $m 2$ \\
\hline & & MPM-PV 20111 & Caviomorpha & 2 incisors \\
\hline & & MPM-PV 20112 & cf. Scleromys & right P4 \\
\hline & & MPM-PV 20113 & Neoreomys? & mandibular fragment with incisor \\
\hline & & MPM-PV 20114 & Eocardia $s p$. & right $m 1$ or $m 2$ \\
\hline & & MPM-PV 20115 & Spaniomys riparius & left mandibular fragment with $d p 4-m 2$ \\
\hline & & MPM-PV 20116 & Perimys erutus & left $M 1$ or $M 2$ \\
\hline & & MPM-PV 20117 & Sciamys sp. & left $M 1$ or $M 2$ \\
\hline & & MPM-PV 20118 & Phanomys sp. & left M1 \\
\hline & & MPM-PV 20119 & Phanomys $s p$. & left $p 4$ \\
\hline & & MPM-PV 20773 & Eocardia $s p$. & broken tooth \\
\hline & & MPM-PV 20774 & Caviomorpha & brachydont molar \\
\hline & & MPM-PV 20775 & Caviomorpha & brachydont molar \\
\hline & & MPM-PV 20776 & Eocardia $s p$. & left lower molar \\
\hline & & MPM-PV 20777 & Eocardia $s p$. & left $m 2$ or $m 3$ \\
\hline & & MPM-PV 20778 & Eocardia $s p$. & left $m 3$ \\
\hline & & MPM-PV 20779 & Eocardia $s p$. & right mandibular fragment with molar \\
\hline & & MPM-PV 20120 & Neoreomys australis & right lower molar \\
\hline
\end{tabular}




\section{Appendix 1 - Continued}

\begin{tabular}{|c|c|c|c|c|}
\hline Locality & Estancia & Collection number & Systematic taxonomy & Material \\
\hline & & MPM-PV 20121 & Neoreomys australis & left $M 1$ or $M 2$ \\
\hline & & MPM-PV 20122 & Eocardia $s p$. & left upper molar \\
\hline & & MPM-PV 20123 & Octodontoidea & left lower incisor \\
\hline & & MPM-PV 20124 & Neoreomys australis & left lower molar \\
\hline & & MPM-PV 20125 & Neoreomys australis & right upper molar \\
\hline & & MPM-PV 20126 & Neoreomys? & lower incisor fragment \\
\hline & & MPM-PV 20127 & Octodontoidea & incisor fragment \\
\hline & & MPM-PV 20128 & Neoreomys australis & left $p 4$ \\
\hline & & MPM-PV 20129 & Neoreomys australis & left $m 1$ or $m 2$ \\
\hline & & MPM-PV 20130 & Neoreomys australis & left m3 (broken) \\
\hline & & MPM-PV 20131 & Neoreomys australis & lower tooth? \\
\hline & & MPM-PV 20132 & Neoreomys australis & right $P 4$ \\
\hline & & MPM-PV 20133 & Neoreomys australis & right $M 1$ or $M 2$ \\
\hline & & MPM-PV 20134 & Sciamys principalis & left lower molar \\
\hline & & MPM-PV 20135 & Stichomys sp. & left $D P 4$ \\
\hline & & MPM-PV 20136 & Stichomys sp. & right $M 1$ or $M 2$ \\
\hline & & MPM-PV 20137 & Stichomys sp. & left lower molar \\
\hline & & MPM-PV 20138 & Perimys incavatus & right upper molar \\
\hline & & MPM-PV 20139 & "Eocardia" excavata & left $m 1$ \\
\hline & & MPM-PV 20140 & Eocardia $s p$. & right lower molar (broken) \\
\hline & & MPM-PV 20141 & Phanomys/ Eocardia & left M1 or M3 \\
\hline & & MPM-PV 20142 & Caviomorpha? & long bone \\
\hline & & MPM-PV 20143 & Spaniomys sp. & right mandible with $m 1-m 2$ \\
\hline & & MPM-PV 20144 & Phanomys mixtus & left M1 or M2 \\
\hline & & MPM-PV 20145 & Neoreomys australis & left mandible with $p 4-m 1$ \\
\hline & & MPM-PV 20146 & Neoreomys australis & right upper molar \\
\hline & & MPM-PV 20147 & Neoreomys australis & left lower molar \\
\hline & & MPM-PV 20148 & Neoreomys australis & left $m 1$ (broken)-m2 and left molar \\
\hline & & MPM-PV 20149 & Spaniomys sp. & left mandible with m1(broken)-m2 \\
\hline & & MPM-PV 20150 & Neoreomys australis & right upper molar (broken) \\
\hline & & MPM-PV 20151 & Perimys $s p$. & right P4 \\
\hline & & MPM-PV 20152 & Eocardia $s p$. & right lower molar \\
\hline & & MPM-PV 20153 & Neoreomys australis & $\begin{array}{l}\text { mandibular symphysis with right } m 1, m 2 \text {, and } \\
p 4 ; \text { and left } 1, m 2, \text { and } p 4\end{array}$ \\
\hline & & MPM-PV 20154 & Neoreomys australis & 3 incisor fragments \\
\hline & & MPM-PV 20155 & Perimys $s p$. & upper molar \\
\hline & & MPM-PV 20156 & Eocardia $s p$. & right upper molar fragment \\
\hline & & MPM-PV 20157 & Spaniomys sp. & right maxillary with DP4-M2 \\
\hline & & MPM-PV 20158 & Perimys $s p$ & right lower molar \\
\hline & Estancia & MPM-PV 20159 & Neoreomys australis & right lower molar \\
\hline & Santa Lucia (ESL) & MPM-PV 20160 & Perimys onustus & right mandible with $p 4-m 1$ \\
\hline & & MPM-PV 20161 & Perimys erutus & right mandibular fragment with $p 4$ \\
\hline & & MPM-PV 20162 & Perimys erutus & right mandibular fragment with $p 4-m 1$ \\
\hline & & MPM-PV 20163 & Perimys erutus & left mandible with p4(broken)-m3 \\
\hline & & MPM-PV 20164 & Perimys erutus & left $m 3$ \\
\hline & & MPM-PV 20165 & Eocardia montana & right mandible with $m 1-m 2$ \\
\hline & & MPM-PV 20166 & Neoreomys australis & right maxilla with DP4-M1 \\
\hline & & MPM-PV 20167 & Caviomorpha? & petrosal \\
\hline
\end{tabular}


Appendix 1 - Continued

\begin{tabular}{|c|c|c|c|c|}
\hline Locality & Estancia & Collection number & Systematic taxonomy & Material \\
\hline & & MPM-PV 20168 & Eocardidae & right mandible with cheek teeth \\
\hline & & MPM-PV 20169 & Neoreomys? & broken molar \\
\hline & & MPM-PV 20170 & Scleromys $s p$. & right $P 4$ \\
\hline & & MPM-PV 20171 & Perimys $s p$. & left upper tooth \\
\hline & & MPM-PV 20172 & Neoreomys australis & left $m 1$ or $m 2$ \\
\hline & & MPM-PV 20173 & Neoreomys australis? & incisor \\
\hline & & MPM-PV 20174 & Eocardia $s p$. & tooth fragments and left DP4 \\
\hline & & MPM-PV 20175 & Acaremys $s p$. & $p 4, m 1$, and incisor \\
\hline & & MPM-PV 20176 & Rodentia & edentulous right maxillary \\
\hline & & MPM-PV 20177 & Perimys $s p$. & left lower tooth \\
\hline & & MPM-PV 20178 & Spaniomys $s p$. & left mandible with $m 1-m 3$ and incisor \\
\hline & & MPM-PV 20179 & Spaniomys $s p$. & right mandible with dp4-m2 \\
\hline & & MPM-PV 20180 & Spaniomys sp. & right maxillary fragment with DP4-M1 \\
\hline & & MPM-PV 20181 & Neoreomys australis & right mandibular fragment with $m 1$ \\
\hline & & MPM-PV 20182 & Spaniomys $s p$ & right mandible with $m 1-m 2$ \\
\hline & & MPM-PV 20183 & Eocardia montana & right mandibular fragment with $m 2$ \\
\hline & & MPM-PV 20184 & Octodontoidea & broken posterior portion of a lower tooth \\
\hline & & MPM-PV 20185 & Acaremyidae & left upper molar \\
\hline & & MPM-PV 20186 & Eocardia $s p$. & left M1 \\
\hline & & MPM-PV 20187 & Eocardia $s p$. & left M1 \\
\hline & & MPM-PV 20188 & Eocardia $s p$. & 3 tooth fragments \\
\hline & & MPM-PV 20189 & Perimys erutus & right mandibular fragment with $p 4$ \\
\hline & & MPM-PV 20190 & Perimys erutus & left mandibular fragment with $p 4$ \\
\hline & & MPM-PV 20191 & Perimys $s p$. & broken tooth \\
\hline & & MPM-PV 20192 & Stichomys $s p$. & right $M 1$ or $M 2$ \\
\hline & & MPM-PV 20193 & Phanomys? & broken lower tooth \\
\hline & & MPM-PV 20194 & Neoreomys australis & left mandibular fragment with m1-m3 \\
\hline & & MPM-PV 20195 & Neoreomys australis & right upper molar \\
\hline & & MPM-PV 20196 & Neoreomys australis & left m3 \\
\hline & & MPM-PV 20197 & Neoreomys australis & left $m 3$ \\
\hline & & MPM-PV 20198 & Neoreomys australis & right p4 \\
\hline & & MPM-PV 20199 & Neoreomys australis & right mandibular fragment with $m 1$ or $m 2$ \\
\hline & & MPM-PV 20200 & Neoreomys australis & left $m 1$ or $m 2$ \\
\hline & & MPM-PV 20201 & Spaniomys $s p$. & left mandibular fragment with $m 1-m 2$ \\
\hline & & MPM-PV 20202 & Spaniomys $s p$. & left M3 \\
\hline & & MPM-PV 20203 & Spaniomys $s p$. & left upper molar \\
\hline & & MPM-PV 20204 & Perimys erutus & right M3 \\
\hline & & MPM-PV 20205 & Octodontoidea & left mandibular fragment with dp4 \\
\hline & & MPM-PV 20206 & Eocardia $s p$. & left upper molar (broken) \\
\hline & & MPM-PV 20207 & Prospaniomys sp. nov.? & left lower molar \\
\hline & & MPM-PV 20208 & Perimys erutus & right $P 4$ \\
\hline & & MPM-PV 20209 & Octodontoidea & right upper incisor \\
\hline & & MPM-PV 20210 & Eocardia $s p$. & left lower molar \\
\hline & & MPM-PV 20211 & Rodentia? & metapodial \\
\hline & & MPM-PV 20212 & Scleromys sp. & left upper molar \\
\hline & & MPM-PV 20213 & Neoreomys australis & right upper molar \\
\hline & & MPM-PV 20214 & Neoreomys australis? & incisor fragment \\
\hline & & MPM-PV 20215 & Neoreomys australis? & incisor fragment \\
\hline & & MPM-PV 20216 & Acaremys sp. & left mandibular fragment with m2-m3(broken) \\
\hline & & MPM-PV 20217 & Neoreomys australis & right lower molar \\
\hline
\end{tabular}


Appendix 1 - Continued

\begin{tabular}{|c|c|c|c|c|}
\hline Locality & Estancia & Collection number & Systematic taxonomy & Material \\
\hline \multirow{50}{*}{$S B B$} & \multirow{50}{*}{$\begin{array}{l}\text { Estancia } \\
\text { Cordón Alto (ECA) }\end{array}$} & MPM-PV 20218 & Caviomorpha & left auditory fragment \\
\hline & & MPM-PV 20219 & Neoreomys australis & right $P 4$ \\
\hline & & MPM-PV 20220 & Neoreomys australis & right upper molar \\
\hline & & MPM-PV 20221 & Neoreomys australis & right upper molar \\
\hline & & MPM-PV 20222 & Neoreomys australis & right M3 \\
\hline & & MPM-PV 20223 & Eocardia $s p$. & palatal fragment with broken left P4 \\
\hline & & MPM-PV 20224 & Eocardia $s p$ & right maxilla with $M 2-M 3$ \\
\hline & & MPM-PV 20225 & Eocardia $s p$ & 2 broken upper tooth and 3 maxillary fragments \\
\hline & & MPM-PV 20226 & Eocardia $s p$. & right $m 1$ or $m 2$ \\
\hline & & MPM-PV 20227 & Neoreomys australis & left M3? \\
\hline & & MPM-PV 20228 & Neoreomys australis & right $P 4$ \\
\hline & & MPM-PV 20229 & Eocardia $s p$. & right upper molar \\
\hline & & MPM-PV 20230 & Spaniomys $s p$. & right upper molar \\
\hline & & MPM-PV 20231 & Prolagostomus $s p$ & broken molar \\
\hline & & MPM-PV 20232 & Prolagostomus $s p$ & broken molar \\
\hline & & MPM-PV 20233 & Neoreomys australis? & incisor fragment \\
\hline & & MPM-PV 20234 & Neoreomys australis & left $m 3$ \\
\hline & & MPM-PV 20235 & Neoreomys australis? & incisor fragment \\
\hline & & MPM-PV 20236 & Spaniomys $s p$. & left mandibular fragment with $m$ 1-m2 \\
\hline & & MPM-PV 20237 & Stichomys regularis & left mandibular fragment with $m 1-m 2$ \\
\hline & & MPM-PV 20238 & Prolagostomus $s p$. & isolated tooth \\
\hline & & MPM-PV 20239 & Pliolagostomus notatus & left lower molar \\
\hline & & MPM-PV 20240 & Pliolagostomus notatus & left lower molar \\
\hline & & MPM-PV 20241 & "Eocardia" excavata & right maxilla with $P 4-M 3$ \\
\hline & & MPM-PV 20242 & Prolagostomus $s p$. & right lower molar \\
\hline & & MPM-PV 20243 & Acaremyidae & right lower molar \\
\hline & & MPM-PV 20244 & "Eocardia" excavata & right $m 1$ \\
\hline & & MPM-PV 20245 & "Eocardia" excavata & right $m 2$ \\
\hline & & MPM-PV 20246 & Octodontoidea & edentulous left mandible \\
\hline & & MPM-PV 20247 & Acaremyidae & right upper molar \\
\hline & & MPM-PV 20248 & Scleromys $s p$. & left $p 4$ \\
\hline & & MPM-PV 20249 & Stichomys $s p$. & left DP4 \\
\hline & & MPM-PV 20250 & Phanomys sp. & left upper molar \\
\hline & & MPM-PV 20251 & Pliolagostomus notatus & 2 right low molars \\
\hline & & MPM-PV 20252 & Pliolagostomus notatus & left lower molar \\
\hline & & MPM-PV 20253 & Pliolagostomus notatus & 2 left lower molars \\
\hline & & MPM-PV 20254 & Pliolagostomus notatus & right p4 \\
\hline & & MPM-PV 20255 & Prolagostomus pusillus & 2 left $p 4 s$ \\
\hline & & MPM-PV 20256 & Prolagostomus pusillus & right $p 4$ \\
\hline & & MPM-PV 20257 & Prolagostomus pusillus & left upper molar \\
\hline & & MPM-PV 20258 & Prolagostomus pusillus & right upper molar \\
\hline & & MPM-PV 20259 & Pliolagostomus/Prolagostomus & 2 broken tooth \\
\hline & & MPM-PV 20260 & Prolagostomus pusillus & left lower molar \\
\hline & & MPM-PV 20261 & Perimys onustus & right lower molar \\
\hline & & MPM-PV 20262 & Prolagostomus pusillus & left lower tooth \\
\hline & & MPM-PV 20263 & Neoreomys australis & right lower molar (broken) \\
\hline & & MPM-PV 20264 & "Eocardia" excavata & right M3 (broken) \\
\hline & & MPM-PV 20265 & Eocardia $s p$ & left lower molar \\
\hline & & MPM-PV 20266 & Pliolagostomus notatus & right lower molar \\
\hline & & MPM-PV 20267 & Prolagostomus $s p$ & right lower molar \\
\hline
\end{tabular}


ApPendix 1 - Continued

\begin{tabular}{|c|c|c|c|c|}
\hline Locality & Estancia & Collection number & Systematic taxonomy & Material \\
\hline & & MPM-PV 20268 & Acarechimys? & right lower incisor \\
\hline & & MPM-PV 20269 & Neoreomys australis & left upper molar \\
\hline & & MPM-PV 20270 & Neoreomys australis & right upper molar (broken) \\
\hline & & MPM-PV 20271 & Perimys onustus & broken molar \\
\hline & & MPM-PV 20272 & Acaremys murinus & right mandibular fragment with m1-m3 \\
\hline & & MPM-PV 20273 & Eocardia montana? & right p4 \\
\hline & & MPM-PV 20274 & Eocardia montana? & right $m 1$ \\
\hline & & MPM-PV 20275 & Eocardia montana? & left $m 1$ or $m 2$ \\
\hline & & MPM-PV 20276 & Stichomys regularis & left mandibular fragment with $m 1-m 2$ \\
\hline & & MPM-PV 20277 & Stichomys regularis & right mandibular fragment with $m 2-m 3$ \\
\hline & & MPM-PV 20278 & Prolagostomus sp. & lower cheek teeth \\
\hline & & MPM-PV 20279 & Eocardia montana & left $m 1$ or $m 2$ \\
\hline & & MPM-PV 20280 & Eocardia montana & right p4 \\
\hline & & MPM-PV 20281 & Eocardia montana & right $m 1$ \\
\hline & & MPM-PV 20282 & Eocardia montana & right $m 2$ \\
\hline & & MPM-PV 20283 & Neoreomys australis & right maxillary fragment with $M 1-M 2$ \\
\hline & & MPM-PV 20284 & Neoreomys australis & left $M 1$ or $M 2$ \\
\hline & & MPM-PV 20285 & Neoreomys australis & right M3 \\
\hline & & MPM-PV 20286 & Neoreomys australis & left M3 \\
\hline & & MPM-PV 20287 & Neoreomys australis & left $M 1$ or $M 2$ \\
\hline & & MPM-PV 20288 & Neoreomys australis & right $m 1$ \\
\hline & & MPM-PV 20289 & Neoreomys australis & right $m 2$ \\
\hline & & MPM-PV 20290 & Neoreomys australis & right $m 3$ \\
\hline & & MPM-PV 20291 & Scleromys $s p$ & left P4 \\
\hline & & MPM-PV 20292 & Neoreomys australis & right maxillary fragment with M1-M3 \\
\hline & & MPM-PV 20295 & Eocardia $s p$. & right maxillary fragment with DP4-M1 \\
\hline & & MPM-PV 20296 & Eocardia $s p$. & right upper molar \\
\hline & & MPM-PV 20297 & Pliolagostomus notatus & left upper molar \\
\hline & & MPM-PV 20298 & Octodontoidea & left upper incisor \\
\hline & & MPM-PV 20299 & Spaniomys $s p$. & right mandible with dp4-m2 \\
\hline & & MPM-PV 15098 & Acarechimys minutissimus & left mandible with dp4 and broken incisor \\
\hline & & MPM-PV 20300 & Eocardia montana & right mandible with $m 1-m 2$ \\
\hline & & MPM-PV 20301 & Eocardia montana & right m3 \\
\hline & & MPM-PV 20302 & Prolagostomus $s p$. & left $m 3$ \\
\hline & & MPM-PV 20303 & Caviomorpha & mandibular fragment with broken incisor \\
\hline & & MPM-PV 20304 & Stichomys $s p$. & left mandibular fragment with $m 2$ \\
\hline & & MPM-PV 20305 & Prolagostomus $s p$ & right lower molar \\
\hline & & MPM-PV 20306 & Eocardia montana? & $\begin{array}{l}\text { right mandibular fragment with } p 4-m 2 \text { and } \\
\text { broken incisor }\end{array}$ \\
\hline & & MPM-PV 20307 & Eocardia montana? & left $m 1$ or $m 2$ \\
\hline & & MPM-PV 20308 & Sciamys principalis & right mandible with $p 4-m 3$ \\
\hline & & MPM-PV 20309 & Octodontoidea & left mandibular fragment with incisor \\
\hline & & MPM-PV 20310 & Spaniomys $s p$. & left maxillary fragment with M1-M2 \\
\hline & & MPM-PV 20311 & Octodontoidea & right lower incisor fragment \\
\hline & & MPM-PV 20312 & Eocardia montana & right mandible with $p 4-m 3$ \\
\hline & & MPM-PV 20313 & Neoreomys australis & right upper molar (broken) \\
\hline & & MPM-PV 20314 & Prolagostomus $s p$. & $\begin{array}{l}\text { left mandibular fragment with } p 4-m 2 \text { and } \\
\text { incisor }\end{array}$ \\
\hline & & MPM-PV 20315 & Prolagostomus $s p$. & left M3 \\
\hline & & MPM-PV 20316 & Prolagostomus $s p$. & isolated incisor \\
\hline
\end{tabular}


APPENDIX 1 - Continued

\begin{tabular}{|c|c|c|c|c|}
\hline Locality & Estancia & Collection number & Systematic taxonomy & Material \\
\hline & & MPM-PV 20317 & Prolagostomus pusillus & right maxillary fragment with $\mathrm{M} 1-\mathrm{M} 2$ \\
\hline & & MPM-PV 20318 & Prolagostomus pusillus & right mandible with $m 1-m 3$ \\
\hline & & MPM-PV 20319 & Pliolagostomus? & M3? \\
\hline & & MPM-PV 20320 & Pliolagostomus? & right mandibular fragment with $p 4$ \\
\hline & & MPM-PV 15091 & Acarechimys constans & right mandible with dp4-m2 \\
\hline & & MPM-PV 20321 & Perimys erutus & right mandible with $p 4-m 3$ \\
\hline & & MPM-PV 20322 & Prolagostomus $s p$. & left lower molar \\
\hline & & MPM-PV 20323 & Neoreomys australis & right lower molar \\
\hline & & MPM-PV 20324 & Neoreomys australis & right lower molar \\
\hline & & MPM-PV 20325 & Neoreomys australis & left $P 4$ \\
\hline & & MPM-PV 20326 & Eocardia montana & left mandible with $p 4-m 3$ \\
\hline & & MPM-PV 20327 & Eocardia montana & left $m 2$ or $m 3$ \\
\hline & & MPM-PV 20328 & Eocardia? & portion of a lower incisor \\
\hline & & MPM-PV 20329 & Neoreomys australis & right $M 1$ or $M 2$ \\
\hline & & MPM-PV 20330 & Neoreomys australis & left $M 1$ or $M 2$ \\
\hline & & MPM-PV 20331 & Neoreomys australis & right $M 1$ or $M 2$ \\
\hline & & MPM-PV 20332 & Neoreomys australis & right upper premolar \\
\hline & & MPM-PV 20333 & Neoreomys australis & left upper molar \\
\hline & & MPM-PV 20334 & Neoreomys? & 2 incisor fragments \\
\hline & & MPM-PV 20335 & Stichomys $s p$. & mandibular fragment with $m 2$ \\
\hline & & MPM-PV 20336 & Prolagostomus $s p$ & right lower molar \\
\hline & & MPM-PV 20337 & Spaniomys sp. & right lower molar \\
\hline & & MPM-PV 20338 & Stichomys $s p$. & right lower molar \\
\hline & & MPM-PV 20339 & cf. Scleromys & upper tooth fragment \\
\hline & & MPM-PV 20340 & Octodontoidea & edentulous left mandibular fragment \\
\hline & & MPM-PV 20341 & Stichomys $s p$. & right $D P 4-M 1$ \\
\hline & & MPM-PV 20342 & Stichomys $s p$. & left $M 1$ or $M 2$ \\
\hline & & MPM-PV 20343 & Prolagostomus pusillus & left $p 4-m 2$ \\
\hline & & MPM-PV 20344 & Neoreomys? & right upper molar (broken) \\
\hline & & MPM-PV 20345 & Stichomys? & lower incisor \\
\hline & & MPM-PV 20346 & Acarechimys minutissimus & left mandible with $p 4-m 3$ \\
\hline & & MPM-PV 20347 & Stichomys $s p$. & left $D P 4$ \\
\hline & & MPM-PV 20348 & Prolagostomus sp. & right p4 \\
\hline & & MPM-PV 20349 & Prolagostomus/Pliolagostomus & upper molar \\
\hline & & MPM-PV 20350 & Rodentia? & humerous distal portion \\
\hline & & MPM-PV 20351 & Rodentia? & metatarsal? \\
\hline & & MPM-PV 20352 & Sciamys $s p$. & left mandible with $p 4-m 1$ and incisor \\
\hline & & MPM-PV 20353 & Pliolagostomus notatus & left lower tooth \\
\hline & & MPM-PV 20354 & Eocardia $s p$ & lower molar fragment \\
\hline & & MPM-PV 20355 & Perimys onustus & right mandible with $m 1-m 3$ \\
\hline & & MPM-PV 20356 & Stichomys/ Adelphomys & right mandible with dp4-m2 \\
\hline & & MPM-PV 20357 & Neoreomys australis & left upper molar \\
\hline & & MPM-PV 20358 & Neoreomys australis & right lower molar \\
\hline & & MPM-PV 20359 & Prolagostomus pusillus & left upper molar \\
\hline & & MPM-PV 20360 & Pliolagostomus notatus & left lower molar \\
\hline & & MPM-PV 20361 & Neoreomys australis & skull fragment and broken teeth \\
\hline & & MPM-PV 20362 & Prolagostomus pusillus & $\begin{array}{l}\text { right mandibular fragment with p4-m2(bro- } \\
\text { ken) and incisor }\end{array}$ \\
\hline & & MPM-PV 20363 & Eocardia $s p$. & right p4 \\
\hline & & MPM-PV 20364 & Acarechimys minutissimus & right mandible with $m 1-m 3$ \\
\hline
\end{tabular}


ApPendix 1 - Continued

\begin{tabular}{|c|c|c|c|c|}
\hline Locality & Estancia & Collection number & Systematic taxonomy & Material \\
\hline & & MPM-PV 20365 & Eocardia $s p$. & right $m 3$ \\
\hline & & MPM-PV 20366 & Neoreomys australis & right lower molar \\
\hline & & MPM-PV 20367 & Prolagostomus pusillus & right mandible with m1-m3(broken) \\
\hline & & MPM-PV 20368 & Prolagostomus pusillus & maxilla with right and left P4-M3 \\
\hline & & MPM-PV 15100 & Acarechimys minutissimus & right mandible with dp4(broken)-m2 \\
\hline & & MPM-PV 15101 & Acarechimys minutissimus & right mandible with dp4-m1 \\
\hline & & MPM-PV 20369 & Eocardia $s p$. & left upper cheek teeth \\
\hline & & MPM-PV 20370 & Perimys $s p$. & right lower molar \\
\hline & & MPM-PV 20371 & Prolagostomus pusillus & left maxillary fragment with P4-M3 \\
\hline & & MPM-PV 15092 & Acarechimys constans? & right mandible with dp4-m2 and incisor \\
\hline & & MPM-PV 20372 & Steiromys? & left maxillary fragment with P4-M1 \\
\hline & & MPM-PV 20373 & Stichomys $s p$. & left $M 1$ or $M 2$ \\
\hline & & MPM-PV 20374 & Eocardia $s p$ & left mandible with $m 1$ or $m 2$ \\
\hline & & MPM-PV 20375 & Perimys onustus & left mandibular fragment with $p 4$ \\
\hline & & MPM-PV 20376 & Prolagostomus pusillus & $\begin{array}{l}\text { left mandibular fragment with } p 4-m 3 \text { and } \\
\text { broken incisor }\end{array}$ \\
\hline & & MPM-PV 20377 & Prolagostomus $s p$. & left maxillary fragment with P4-M2 \\
\hline & & MPM-PV 20378 & Eocardia $s p$. & left upper molar \\
\hline & & MPM-PV 20379 & Prolagostomus pusillus & right $p 4$ \\
\hline & & MPM-PV 20380 & Prolagostomus pusillus & right lower cheek teeth \\
\hline & & MPM-PV 20381 & Prolagostomus/Pliolagostomus & broken cheek teeth \\
\hline & & MPM-PV 20382 & Prolagostomus/Pliolagostomus & broken cheek teeth \\
\hline & & MPM-PV 20383 & Acarechimys? & right mandible with $m 1-m 2$ \\
\hline & & MPM-PV 20384 & Steiromys detentus & right mandible with dp4-m3(broken) \\
\hline & & MPM-PV 20385 & Perimys onustus & left lower molar \\
\hline & & MPM-PV 20386 & Neoreomys australis & right upper molar \\
\hline & & MPM-PV 20387 & Pliolagostomus notatus & left M3 \\
\hline & & MPM-PV 20388 & Acarechimys minutissimus & right mandible with $m 1-m 3$ \\
\hline & & MPM-PV 20389 & Spaniomys sp. & right maxillary fragment with $\mathrm{M} 1-\mathrm{M} 3$ \\
\hline & & MPM-PV 20390 & Spaniomys sp. & left maxillary fragment with M1-M2 \\
\hline & & MPM-PV 20391 & Sciamys principalis & right mandibular fragment with $p 4-m 2$ \\
\hline & & MPM-PV 15099 & Acarechimys minutissimus & left mandible with m1-m2 and broken incisor \\
\hline & & MPM-PV 20392 & Spaniomys sp. & M2-M3 \\
\hline & & MPM-PV 20393 & Eocardia $s p$. & right upper molar \\
\hline & & MPM-PV 20394 & Eocardia montana & right upper molar \\
\hline & & MPM-PV 20395 & Perimys $s p$. & left $M 1$ or $M 2$ \\
\hline & & MPM-PV 20396 & Prolagostomus $s p$. & left M3 \\
\hline & & MPM-PV 20397 & Prolagostomus $s p$. & left lower molar \\
\hline & & MPM-PV 20398 & Prolagostomus/Pliolagostomus & broken tooth \\
\hline & & MPM-PV 20399 & Cavioidea & broken tooth \\
\hline & & MPM-PV 20400 & Eocardia $s p$. & isolated $m 1$ or $m 2$ \\
\hline & & MPM-PV 20401 & Eocardia montana & left mandible with $p 4-m 2$ \\
\hline & & MPM-PV 20402 & Eocardia $s p$ & left $m 3$ \\
\hline & & MPM-PV 20403 & Prolagostomus pusillus & right M3 \\
\hline & & MPM-PV 20404 & Prolagostomus pusillus & left lower molar \\
\hline & & MPM-PV 20405 & Pliolagostomus notatus & right maxillary fragment with P4-M3 \\
\hline & & MPM-PV 20406 & Pliolagostomus notatus & left lower molar \\
\hline & & MPM-PV 20407 & Prolagostomus/Pliolagostomus & left $p 4$ \\
\hline & & MPM-PV 20408 & Neoreomys australis & right lower molar \\
\hline & & MPM-PV 20409 & Eocardia montana & left mandible with dp4-m1 and incisor \\
\hline
\end{tabular}


Appendix 1 - Continued

\begin{tabular}{|c|c|c|c|c|}
\hline Locality & Estancia & Collection number & Systematic taxonomy & Material \\
\hline & \multirow{49}{*}{$\begin{array}{l}\text { Estancia } \\
\text { Cordón Alto2 (ECA2) }\end{array}$} & MPM-PV 20410 & Eocardia $s p$. & right M3 \\
\hline & & MPM-PV 20411 & Eocardia $s p$. & right lower molar \\
\hline & & MPM-PV 20412 & $c f$. Neoreomys & lower isolated molar \\
\hline & & MPM-PV 20413 & Pliolagostomus notatus & right upper molar \\
\hline & & MPM-PV 20414 & Prolagostomus sp. & left mandibular fragment with $p 4-m 2$ \\
\hline & & MPM-PV 20415 & Stichomys $s p$. & left mandibular fragment with m1-m3 \\
\hline & & MPM-PV 20416 & Spaniomys $s p$. & left lower molar \\
\hline & & MPM-PV 20417 & Neoreomys australis & left dp4 \\
\hline & & MPM-PV 20418 & $c f$. Neoreomys & right dp4 \\
\hline & & MPM-PV 20419 & Phanomys? & left upper molar \\
\hline & & MPM-PV 20420 & Eocardia montana & left upper molar \\
\hline & & MPM-PV 20421 & Perimys $s p$. & left $p 4 ?$ \\
\hline & & MPM-PV 20422 & Pliolagostomus notatus & right lower molar \\
\hline & & MPM-PV 20423 & Neoreomys australis & left $m 1$ or $m 2$ \\
\hline & & MPM-PV 20424 & Sciamys principalis & left mandibular fragment with $p 4$ (broken)- $m 1$ \\
\hline & & MPM-PV 20425 & Spaniomys $s p$. & left mandibular fragment with $m 1-m 2$ \\
\hline & & MPM-PV 20426 & Stichomys sp. & left mandibular fragment with dp4-m2 \\
\hline & & MPM-PV 20427 & Prolagostomus $s p$ & left M3 \\
\hline & & MPM-PV 20428 & Prolagostomus $s p$ & left lower molar \\
\hline & & MPM-PV 20429 & Stichomys $s p$. & $\begin{array}{l}\text { right mandibular fragment with } m 1 \text { and } \\
\text { incisor }\end{array}$ \\
\hline & & MPM-PV 20430 & Stichomys?/Adelphomys? & left DP4 \\
\hline & & MPM-PV 20431 & Eocardia $s p$. & right mandibular fragment with $p 4-m 2$ \\
\hline & & MPM-PV 20432 & Eocardia? & right M3 \\
\hline & & MPM-PV 20433 & Eocardia $s p$. & right upper molar \\
\hline & & MPM-PV 20434 & Neoreomys australis & right lower molar \\
\hline & & MPM-PV 20435 & Neoreomys australis & left M3 \\
\hline & & MPM-PV 20436 & Prolagostomus $s p$ & left mandible with $p 4$ and incisor \\
\hline & & MPM-PV 20437 & Neoreomys australis & left upper tooth \\
\hline & & MPM-PV 20438 & Neoreomys australis & left $p 4$ \\
\hline & & MPM-PV 20439 & Neoreomys australis & right lower molar (broken) \\
\hline & & MPM-PV 20440 & Neoreomys australis & P4 \\
\hline & & MPM-PV 20441 & Eocardia $s p$ & left lower molar \\
\hline & & MPM-PV 20442 & Steiromys detentus & right mandibular fragment with $p 4-m 3$ \\
\hline & & MPM-PV 20443 & Perimys erutus & right mandibular fragment with $p 4-m 1$ \\
\hline & & MPM-PV 20444 & Stichomys regularis & left mandibular fragment with dp4-m2 \\
\hline & & MPM-PV 20445 & Spaniomys $s p$. & right mandible with $m 1-m 2$ \\
\hline & & MPM-PV 20446 & Prolagostomus sp. & right maxillary fragment with M1-M2 \\
\hline & & MPM-PV 20447 & Stichomys $s p$. & right mandible with $m 1-m 2$ \\
\hline & & MPM-PV 20448 & Pliolagostomus notatus & right maxillary fragment with M1-M2 \\
\hline & & MPM-PV 20449 & Spaniomys $s p$. & left upper molar \\
\hline & & MPM-PV 20450 & Eocardia $s p$. & right $M 1$ or $M 2$ \\
\hline & & MPM-PV 20451 & Eocardia $s p$. & broken upper molar \\
\hline & & MPM-PV 20452 & Eocardia montana & lower molar \\
\hline & & MPM-PV 20453 & Pliolagostomus notatus & right lower molar \\
\hline & & MPM-PV 20454 & Pliolagostomus notatus & left lower molar \\
\hline & & MPM-PV 20455 & Pliolagostomus notatus & left lower molar \\
\hline & & MPM-PV 20456 & Prolagostomus sp. & isolated cheek teeth \\
\hline & & MPM-PV 20457 & Prolagostomus $s p$ & isolated cheek teeth \\
\hline & & MPM-PV 20293 & Neoreomys australis & right maxillary fragment with P4-M1 \\
\hline
\end{tabular}


APPEndix 1 - Continued

\begin{tabular}{|c|c|c|c|c|}
\hline Locality & Estancia & Collection number & Systematic taxonomy & Material \\
\hline & & MPM-PV 20294 & Prospaniomys sp. nov.? & right DP4-M1 \\
\hline & & MPM-PV 20458 & Neoreomys australis & right $P 4$ \\
\hline & & MPM-PV 20459 & Neoreomys australis & right lower molar \\
\hline & & MPM-PV 20460 & Prolagostomus $s p$. & right lower molar \\
\hline & & MPM-PV 20461 & Sciamys principalis & right maxillary fragment with $P 4$ \\
\hline & & MPM-PV 20462 & Sciamys principalis & left mandible with $p 4-m 2$ \\
\hline & & MPM-PV 20463 & Spaniomys sp. & left maxillary fragment with $M 1$ \\
\hline & & MPM-PV 20464 & Spaniomys $s p$. & left upper molar \\
\hline & & MPM-PV 20465 & Spaniomys sp. & right upper molar (broken) \\
\hline & & MPM-PV 20466 & Stichomys $s p$. & right m3 \\
\hline & & MPM-PV 20467 & Acaremyidae & left lower molar \\
\hline & & MPM-PV 20468 & Prolagostomus $s p$. & left lower molar \\
\hline & & MPM-PV 20469 & Octodontoidea & right upper incisor \\
\hline & & MPM-PV 20470 & Caviomorpha & right upper incisor \\
\hline & & MPM-PV 20471 & Caviomorpha & left lower incisor \\
\hline & & MPM-PV 20472 & Pliolagostomus/Prolagostomus & left $p 4$ \\
\hline & & MPM-PV 20473 & Prolagostomus $s p$. & left mandibular fragment with $p 4-m 2$ \\
\hline & & MPM-PV 20474 & Pliolagostomus notatus & right mandibular fragment with $p 4$ \\
\hline & & MPM-PV 20475 & Spaniomys $s p$. & left maxillary fragment with $M 1$ \\
\hline & & MPM-PV 20476 & Spaniomys $s p$. & right maxillary fragment with DP4 \\
\hline & & MPM-PV 20477 & Chinchilloidea & broken teeth \\
\hline & & MPM-PV 20478 & Acarechimys minutus & left mandibular fragment with dp4-mz \\
\hline & & MPM-PV 20479 & Acarechimys minutissimus & left maxillary fragment with DP4-M1 \\
\hline & & MPM-PV 20480 & Acarechimys minutissimus & left maxillary fragment with M1-M2 \\
\hline & & MPM-PV 20481 & Octodontoidea & left mandibular fragment with incisor \\
\hline & & MPM-PV 20482 & Caviomorpha & right mandibular fragment with incisor \\
\hline & & MPM-PV 20483 & Spaniomys $s p$. & right upper cheek teeth \\
\hline & & MPM-PV 20484 & Stichomys $s p$. & right $D P 4$ \\
\hline & & MPM-PV 20485 & Stichomys $s p$. & left upper molar \\
\hline & & MPM-PV 20486 & Stichomys $s p$. & right upper molar \\
\hline & & MPM-PV 20487 & Acaremyidae & broken cheek teeth \\
\hline & & MPM-PV 20488 & Prolagostomus sp. & right cheek teeth \\
\hline & & MPM-PV 20489 & Prolagostomus $s p$. & left cheek teeth \\
\hline & & MPM-PV 20490 & Prolagostomus $s p$. & left cheek teeth \\
\hline & & MPM-PV 20491 & Prolagostomus $s p$. & left cheek teeth \\
\hline & & MPM-PV 20492 & Pliolagostomus notatus & left upper cheek teeth \\
\hline & & MPM-PV 20493 & Pliolagostomus notatus & right $p 4$ \\
\hline & & MPM-PV 20494 & Pliolagostomus notatus & right upper cheek teeth \\
\hline & & MPM-PV 20495 & Pliolagostomus notatus & right upper cheek teeth \\
\hline & & MPM-PV 20496 & Pliolagostomus/Prolagostomus & isolated cheek teeth \\
\hline & & MPM-PV 20497 & Pliolagostomus/Prolagostomus & isolated cheek teeth \\
\hline & & MPM-PV 20498 & Eocardia $s p$ & left lower cheek teeth \\
\hline & & MPM-PV 20499 & Eocardia $s p$. & upper cheek teeth \\
\hline & & MPM-PV 20500 & Octodontoidea & left lower incisor \\
\hline & & MPM-PV 20501 & Octodontoidea & edentulous left mandible \\
\hline & & MPM-PV 20502 & Prolagostomus $s p$. & left M3 \\
\hline & & MPM-PV 20503 & Stichomys $s p$. & right $m 2$ \\
\hline & & MPM-PV 20504 & Prolagostomus $s p$. & isolated cheek teeth \\
\hline & & MPM-PV 20505 & Perimys onustus & left lower molar \\
\hline & & MPM-PV 20506 & Prolagostomus sp. & right $p 4$ \\
\hline
\end{tabular}


APPENDIX 1 - Continued

\begin{tabular}{|c|c|c|c|c|}
\hline Locality & Estancia & Collection number & Systematic taxonomy & Material \\
\hline & & MPM-PV 20507 & Prolagostomus $s p$. & right lower molar \\
\hline & & MPM-PV 20508 & Eocardia $s p$. & left lower molar \\
\hline & & MPM-PV 20509 & Caviomorpha & left mandible with broken incisor \\
\hline & & MPM-PV 20510 & Octodontoidea & left mandible with broken incisor \\
\hline & & MPM-PV 20511 & Prolagostomus $s p$. & left mandibular fragment with p4-m3 \\
\hline & & MPM-PV 20512 & Pliolagostomus/Prolagostomus & isolated broken cheek teeth \\
\hline & & MPM-PV 20513 & Pliolagostomus/Prolagostomus & isolated broken cheek teeth \\
\hline & & MPM-PV 20514 & Stichomys $s p$. & right DP4 \\
\hline & & MPM-PV 20515 & Stichomys $s p$. & left $d p 4$ \\
\hline & & MPM-PV 20516 & Stichomys $s p$. & upper molar (broken) \\
\hline & & MPM-PV 20517 & Neoreomys australis & right lower cheek teeth \\
\hline & & MPM-PV 20518 & Neoreomys australis & right lower cheek teeth \\
\hline & & MPM-PV 20519 & Caviomorpha & incisor \\
\hline & & MPM-PV 20520 & Octodontoidea & incisor \\
\hline & & MPM-PV 20521 & Octodontoidea & left lower incisor \\
\hline & & MPM-PV 20522 & Octodontoidea & left upper incisor \\
\hline & & MPM-PV 20523 & Rodentia? & isolated phalanx \\
\hline & & MPM-PV 20524 & Spaniomys riparius & right mandible with $m 1-m 2$ \\
\hline & & MPM-PV 20525 & Neoreomys australis & left lower tooth \\
\hline & & MPM-PV 20526 & Neoreomys? & upper tooth \\
\hline & & MPM-PV 20527 & Neoreomys? & broken tooth \\
\hline & & MPM-PV 20528 & Prolagostomus sp. & right $m 1-m 2$ \\
\hline & & MPM-PV 20529 & Schistomys erro & right maxillary fragment with $P 4-M 3$ \\
\hline & & MPM-PV 20530 & Prolagostomus $s p$. & left lower molar \\
\hline & & MPM-PV 20531 & Prolagostomus $s p$. & left lower molar \\
\hline & & MPM-PV 20532 & Pliolagostomus/Prolagostomus & isolated tooth \\
\hline & & MPM-PV 20533 & Stichomys $s p$. & $D P 4$ \\
\hline & & MPM-PV 17430 & Acarechimys gracilis & left mandible with dp4-m3 \\
\hline & & MPM-PV 20534 & Perimys $s p$. & right lower molar \\
\hline & & MPM-PV 20535 & Perimys $s p$. & right lower molar (broken) \\
\hline & & MPM-PV 20536 & Chinchilloidea? & left mandibular fragment with incisor \\
\hline & & MPM-PV 20537 & Prolagostomus sp. & right mandibular fragment with $p 4$ \\
\hline & & MPM-PV 20538 & Acaremys murinus & right mandible with $m 2-m 3$ and isolated $m 1$ \\
\hline & & MPM-PV 20539 & Neoreomys australis & left lower molar \\
\hline & & MPM-PV 20540 & Neoreomys australis & broken lower molar \\
\hline & & MPM-PV 20541 & Prolagostomus sp. & lower cheek teeth \\
\hline & & MPM-PV 20542 & Eocardia/ Schistomys & left lower molar \\
\hline & & MPM-PV 20543 & Eocardia montana & right mandibular fragment with $m 2$ \\
\hline & & MPM-PV 20544 & Eocardia $s p$. & left mandibular fragment with $m 1-m 2$ \\
\hline & & MPM-PV 20545 & Eocardia $s p$. & left mandibular fragment with $m 3$ \\
\hline & & MPM-PV 20546 & Caviomorpha & right maxilla with broken incisor \\
\hline & & MPM-PV 20547 & Prolagostomus $s p$. & cheek teeth \\
\hline & & MPM-PV 15093 & Acarechimys constans & right mandible with dp4-m2 \\
\hline & & MPM-PV 15102 & Acarechimys minutissimus & left mandible with $m 1$ \\
\hline & & MPM-PV 17426 & Acarechimys minutissimus & right mandible with $d p 4-m 1$ and incisor \\
\hline & & MPM-PV 20548 & Perimys? & broken tooth \\
\hline & & MPM-PV 20549 & Stichomys regularis & right mandible with $m 1-m 2$ \\
\hline & & MPM-PV 20550 & Stichomys/ Adelphomys & left mandibular fragment with $m 2$ \\
\hline & & MPM-PV 20551 & Perimys onustus & right $p 4$ \\
\hline & & MPM-PV 20552 & Prolagostomus $s p$. & broken tooth \\
\hline
\end{tabular}


APPEndix 1 - Continued

\begin{tabular}{|c|c|c|c|c|}
\hline Locality & Estancia & Collection number & Systematic taxonomy & Material \\
\hline & & MPM-PV 20553 & Eocardia montana & right mandibular fragment with $p 4-m 2$ \\
\hline & & MPM-PV 20554 & Phanomys sp. & right mandible with $p 4-m 1$ \\
\hline & & MPM-PV 20555 & Steiromys detentus & right mandible with p4 and incisor \\
\hline & & MPM-PV 20556 & Spaniomys riparius & right mandible with m1-m2 \\
\hline & & MPM-PV 20557 & Spaniomys riparius & left mandibular fragment with m1-m3 \\
\hline & & MPM-PV 20558 & Spaniomys riparius & left mandibular fragment with m1-m2 \\
\hline & & MPM-PV 20559 & Stichomys regularis & left mandibular fragment with $m 1-m 2$ \\
\hline & & MPM-PV 17433 & Acarechimys gracilis & left mandibular fragment with m1-m2 \\
\hline & & MPM-PV 17434 & Acarechimys gracilis & left mandibular fragment with dp4-mz \\
\hline & & MPM-PV 20560 & Prospaniomys sp. nov.? & upper molar \\
\hline & & MPM-PV 20561 & Dudumus sp. nov.? & right DP4-M1 \\
\hline & & MPM-PV 20562 & Spaniomys $s p$. & left lower molar \\
\hline & & MPM-PV 20563 & Prolagostomus pusillus & right M3 \\
\hline & & MPM-PV 20564 & Prolagostomus pusillus & right mandibular fragment with $p 4-m 2$ \\
\hline & & MPM-PV 20565 & Prolagostomus pusillus & left maxillary fragment with $\mathrm{P} 4$ \\
\hline & & MPM-PV 20566 & Prolagostomus pusillus & left mandibular fragment with $m 2-m 3$ \\
\hline & & MPM-PV 20567 & Prolagostomus $s p$. & right lower molar \\
\hline & & MPM-PV 20568 & Pliolagostomus notatus & right upper molar \\
\hline & & MPM-PV 20569 & Prolagostomus $s p$. & right upper molar? \\
\hline & & MPM-PV 20570 & Prolagostomus $s p$. & left lower molar \\
\hline & & MPM-PV 20571 & Eocardia $s p$ & right upper molar \\
\hline & & MPM-PV 20572 & Neoreomys australis & right upper molar \\
\hline & & MPM-PV 20573 & Prolagostomus $s p$. & left maxillary fragment with M1-M2 \\
\hline & & MPM-PV 20574 & Prolagostomus pusillus & right mandibular fragment with $p 4$ \\
\hline & & MPM-PV 20575 & Stichomys regularis & left $d p 4$ \\
\hline & & MPM-PV 20576 & Pliolagostomus notatus & right maxillary fragment P4-M2 \\
\hline & & MPM-PV 20577 & Perimys onustus & right m3 \\
\hline & & MPM-PV 20578 & Eocardia $s p$. & left mandibular fragment with $p 4-m 1$ \\
\hline & & MPM-PV 20579 & Pliolagostomus/Prolagostomus & left maxilla with P4-M2 (broken) \\
\hline & & MPM-PV 20580 & Pliolagostomus/Prolagostomus & left maxillary fragment with P4-M1 \\
\hline & & MPM-PV 20581 & Eocardia montana & right mandible with dp4-m1 \\
\hline & & MPM-PV 20582 & Eocardia $s p$. & left? broken molar \\
\hline & & MPM-PV 20583 & Neoreomys australis & left lower molar \\
\hline & & MPM-PV 20584 & Neoreomys australis & left lower molar (broken) \\
\hline & & MPM-PV 20585 & Perimys onustus & left $M 1$ or $M 2$ \\
\hline & & MPM-PV 20586 & Prolagostomus pusillus & left maxillary fragment with $\mathrm{P} 4$ \\
\hline & & MPM-PV 20587 & Prolagostomus pusillus & left M1 \\
\hline & & MPM-PV 20588 & Eocardia montana & left $p 4$ \\
\hline & & MPM-PV 20589 & Prolagostomus pusillus & left maxillary fragment with M1-M2 \\
\hline & & MPM-PV 20590 & Prolagostomus $s p$. & left upper molar \\
\hline & & MPM-PV 20591 & Prolagostomus $s p$. & right upper molar \\
\hline & & MPM-PV 20592 & Prolagostomus $s p$. & isolated tooth \\
\hline & & MPM-PV 20593 & Prolagostomus $s p$. & isolated tooth \\
\hline & & MPM-PV 20594 & Prolagostomus $s p$. & left maxillary fragment with $\mathrm{P} 4$ \\
\hline & & MPM-PV 20595 & Acarechimys $s p$. & left maxillary fragment with DP4-M1 \\
\hline & & MPM-PV 20596 & $c f$. Acarechimys minutissimus & left mandibular fragment with dp4-m3 \\
\hline & & MPM-PV 20597 & Prolagostomus sp. & isolated molar \\
\hline & & MPM-PV 20598 & Steiromys detentus & left $p 4$ \\
\hline & & MPM-PV 20599 & Pliolagostomus notatus & left M3 \\
\hline & & MPM-PV 20600 & Prolagostomus pusillus & right $M 3$ \\
\hline
\end{tabular}


APPENDIX 1 - Continued

\begin{tabular}{|c|c|c|c|c|}
\hline Locality & Estancia & Collection number & Systematic taxonomy & Material \\
\hline & & MPM-PV 20601 & Cavioidea & broken tooth \\
\hline & & MPM-PV 20602 & Octodontoidea & maxillary fragment with tooth \\
\hline & & MPM-PV 20603 & Prolagostomus $s p$. & isolated tooth \\
\hline & & MPM-PV 20604 & Prolagostomus $s p$. & right lower molar \\
\hline & & MPM-PV 20605 & Prolagostomus $s p$. & left upper molar \\
\hline & & MPM-PV 20606 & Prolagostomus pusillus & $\begin{array}{l}\text { right mandibular fragment with } p 4 \text { and } \\
\text { broken incisor }\end{array}$ \\
\hline & & MPM-PV 20607 & Prolagostomus $s p$. & left mandibular fragment with $p 4$ \\
\hline & & MPM-PV 20608 & Prolagostomus pusillus & left M3 \\
\hline & & MPM-PV 20609 & Prolagostomus pusillus & left M3 \\
\hline & & MPM-PV 20610 & Prolagostomus pusillus & left M3 \\
\hline & & MPM-PV 20611 & Prolagostomus $s p$. & isolated tooth \\
\hline & & MPM-PV 20612 & Pliolagostomus/Prolagostomus & left $p 4$ \\
\hline & & MPM-PV 20613 & Prolagostomus sp. & right upper molar \\
\hline & & MPM-PV 20614 & Pliolagostomus notatus & left upper molar \\
\hline & & MPM-PV 20615 & Prolagostomus $s p$. & isolated tooth \\
\hline & & MPM-PV 20616 & Prolagostomus $s p$. & broken tooth \\
\hline & & MPM-PV 20617 & Stichomys $s p$. & right $M 1$ or $M 2$ \\
\hline & & MPM-PV 20618 & Spaniomys $s p$. & left mandibular fragment with $m 2$ \\
\hline & & MPM-PV 20619 & Stichomys $s p$. & left $d p 4$ \\
\hline & & MPM-PV 20620 & Stichomys $s p$. & left $m 2$ \\
\hline & & MPM-PV 20621 & Spaniomys $s p$. & upper molar (broken) \\
\hline & & MPM-PV 20622 & Acarechimys? & right DP4-M1 \\
\hline & & MPM-PV 20623 & Octodontoidea & broken upper tooth \\
\hline & & MPM-PV 20624 & Neoreomys australis & left upper molar \\
\hline & & MPM-PV 20625 & Neoreomys australis & left upper molar \\
\hline & & MPM-PV 20626 & Neoreomys australis & left $p 4$ \\
\hline & & MPM-PV 20627 & Prolagostomus pusillus & left $p 4$ \\
\hline & & MPM-PV 20628 & Octodontoidea & left mandible with broken incisor \\
\hline & & MPM-PV 15096 & Acarechimys constans & left mandible with dp4-m2 and incisor \\
\hline & & MPM-PV 20629 & Prolagostomus sp. & right $p 4$ \\
\hline & & MPM-PV 20630 & Steiromys duplicatus & left upper molar \\
\hline & & MPM-PV 20631 & Stichomys $s p$. & left $M 1$ or $M 2$ \\
\hline & & MPM-PV 20632 & Spaniomys sp. & left upper molar \\
\hline & & MPM-PV 20633 & Spaniomys $s p$. & left M3 \\
\hline & & MPM-PV 20634 & Stichomys regularis & left mandibular fragment with $m 2-m 3$ \\
\hline & & MPM-PV 20635 & Neoreomys australis & right upper molar \\
\hline & & MPM-PV 20636 & Neoreomys australis & left lower molar \\
\hline & & MPM-PV 20637 & Acarechimys constans & right mandible with dp4 and incisor \\
\hline & & MPM-PV 20638 & Eocardia / Schistomys & broken tooth \\
\hline & & MPM-PV 20639 & Prolagostomus pusillus & left M3 \\
\hline & & MPM-PV 20640 & Stichomys regularis & left mandible with $m 1-m 2$ and incisor \\
\hline & & MPM-PV 17431 & Acarechimys gracilis & right mandible with $m 1-m 3$ \\
\hline & & MPM-PV 20641 & Acarechimys $s p$. & right mandible with $m 1-m 2$ \\
\hline & & MPM-PV 20642 & Stichomys regularis & left mandible with $d p 4-m 1$ and incisor \\
\hline & & MPM-PV 20643 & Stichomys regularis & right maxillary fragment with DP4-M2 \\
\hline & & MPM-PV 20644 & Stichomys regularis & left maxillary fragment with DP4-M3 \\
\hline & & MPM-PV 20645 & Stichomys regularis & right mandibular fragment with $m 3$ \\
\hline & & MPM-PV 20646 & Spaniomys riparius & right mandible with dp4-m3 \\
\hline & & MPM-PV 20647 & Spaniomys riparius & left maxillary fragment with DP4-M2 \\
\hline
\end{tabular}


ApPendix 1 - Continued

\begin{tabular}{|c|c|c|c|c|}
\hline Locality & Estancia & Collection number & Systematic taxonomy & Material \\
\hline & & MPM-PV 17432 & Acarechimys gracilis & $\begin{array}{l}\text { right mandibular fragment with dp4 } \\
\text { (broken)-m3 }\end{array}$ \\
\hline & & MPM-PV 20648 & Phanomys sp. & right mandible with $m 1-m 2$ \\
\hline & & MPM-PV 20649 & Octodontoidea & edentulous right mandibular fragment \\
\hline & & MMP-PV 17427 & Acarechimys minutissimus & right mandible with dp4-m2 and incisor \\
\hline & & MPM-PV 15094 & Acarechimys constans & left mandibular fragment with $d p 4-m 1$ \\
\hline & & MPM-PV 20650 & Sciamys $s p$. & left maxillary fragment with P4-M3 \\
\hline & & MPM-PV 20651 & Perimys onustus & right maxillary fragment with P4-M3 \\
\hline & & MPM-PV 20652 & Steiromys detentus & left mandibular fragment with $p 4$ \\
\hline & & MPM-PV 20653 & Acaremys sp. & left mandibular fragment with $p 4-m 2$ \\
\hline & & MPM-PV 20654 & caviomorpha? & basicranium/left auditory bulla? \\
\hline & & MPM-PV 20655 & Perimys onustus & left maxillary fragment with P4-M3 \\
\hline & & MPM-PV 15095 & Acarechimys constans & right mandibular fragment with $m 1-m 3$ \\
\hline & & MPM-PV 20656 & Stichomys/ Adelphomys & right $m 1$ \\
\hline & & MPM-PV 20657 & Phanomys $s p$. & right upper molar? \\
\hline & & MPM-PV 20658 & Perimys onustus & right $p 4$ \\
\hline & & MPM-PV 20659 & Perimys onustus & right $p 4$ \\
\hline & & MPM-PV 20660 & Perimys onustus & left $M 1$ or right $M 3$ \\
\hline & & MPM-PV 20661 & Perimys onustus & left lower molar? \\
\hline & & MPM-PV 20662 & Perimys onustus & left lower molar? \\
\hline & & MPM-PV 20663 & Perimys onustus & left lower molar? \\
\hline & & MPM-PV 20664 & Perimys onustus & left lower molar? \\
\hline & & MPM-PV 20665 & Perimys onustus & cheek tooth \\
\hline & & MPM-PV 20666 & Perimys onustus & cheek tooth \\
\hline & & MPM-PV 20667 & Sciamys principalis & right mandible with $p 4-m 3$ \\
\hline & & MPM-PV 20668 & Sciamys latidens & right mandibular fragment with $p 4-m 2$ \\
\hline & & MPM-PV 20669 & Neoreomys australis & right upper molar \\
\hline & & MPM-PV 15097 & Acarechimys constans & right mandible with $m 2-m 3$ \\
\hline & \multirow{22}{*}{$\begin{array}{l}\text { Estancia } \\
\text { El Tordillo (EET) }\end{array}$} & MPM-PV 20670 & Perimys onustus & left mandible with $p 4-m 3$ and incisor \\
\hline & & MPM-PV 20671 & Perimys erutus & right mandible with p4-m3 \\
\hline & & MPM-PV 20672 & Perimys? & right mandible with broken incisor \\
\hline & & MPM-PV 20673 & Perimys? & incisor fragment \\
\hline & & MPM-PV 20674 & Eocardia /Schistomys & right maxillary fragment with M1-M3 \\
\hline & & MPM-PV 20675 & Prolagostomus $s p$. & right lower molar \\
\hline & & MPM-PV 20676 & Neoreomys australis & left $p 4$ \\
\hline & & MPM-PV 20677 & Neoreomys australis & right $p 4$ \\
\hline & & MPM-PV 20678 & Neoreomys australis & right $M 3$ \\
\hline & & MPM-PV 20679 & Neoreomys australis & left lower molar \\
\hline & & MPM-PV 20680 & Neoreomys australis & left lower molar \\
\hline & & MPM-PV 20681 & Neoreomys australis & left P4 \\
\hline & & MPM-PV 20682 & Neoreomys australis & right $p 4$ \\
\hline & & MPM-PV 20683 & Neoreomys australis & left upper molar \\
\hline & & MPM-PV 20684 & Neoreomys australis & left upper molar \\
\hline & & MPM-PV 20685 & Neoreomys australis & left lower molar \\
\hline & & MPM-PV 20686 & Prolagostomus sp. & right mandibular fragment with $p 4-m 2$ \\
\hline & & MPM-PV 20687 & Stichomys regularis & palate with left and right DP4-M3 \\
\hline & & MPM-PV 20688 & Spaniomys $s p$. & right mandible with dp4-m2(broken) \\
\hline & & MPM-PV 20689 & Spaniomys $s p$. & left mandibular fragment with $d p 4-m 3$ \\
\hline & & MPM-PV 20690 & Stichomys $s p$. & right mandible with dp4-m1 \\
\hline & & MPM-PV 20691 & Spaniomys $s p$. & left maxilla with 2 broken teeth \\
\hline
\end{tabular}


APPENDIX 1 - Continued

\begin{tabular}{|c|c|c|c|c|}
\hline Locality & Estancia & Collection number & Systematic taxonomy & Material \\
\hline & & MPM-PV 20692 & Prolagostomus $s p$. & 2 right upper teeth \\
\hline & & MPM-PV 20693 & Spaniomys sp. & left $d p 4$ \\
\hline & & MPM-PV 20694 & Caviomorpha & left mandibular fragment with incisor \\
\hline & & MPM-PV 20695 & Spaniomys $s p$. & right mandibular fragment with $m 1$ \\
\hline & & MPM-PV 20696 & Prolagostomus sp. & right $P 4$ \\
\hline & & MPM-PV 20697 & Stichomys/ Adelphomys & left $m 2$ \\
\hline & & MPM-PV 20698 & Eocardia $s p$. & left upper molar \\
\hline & & MPM-PV 20699 & Spaniomys $s p$. & left upper molar \\
\hline & & MPM-PV 17438 & Acarechimys minutissimus & left mandibular fragment with dp4-m2 \\
\hline & & MPM-PV 15087 & Acarechimys minutus & right mandibular fragment with $m 2$ \\
\hline & & MPM-PV 20700 & Neoreomys australis & right mandible with $m 2-m 3$ \\
\hline & & MPM-PV 20701 & Prolagostomus sp. & left maxillary fragment with P4-M2 \\
\hline & & MPM-PV 20702 & Stichomys $s p$. & right maxillary fragment with DP4-M1 \\
\hline & & MPM-PV 20703 & Stichomys $s p$. & left maxillary fragment with DP4 \\
\hline & & MPM-PV 20704 & Prolagostomus sp. & left upper molar \\
\hline & & MPM-PV 20705 & Prolagostomus $s p$. & left $M 3$ \\
\hline & & MPM-PV 20706 & Pliolagostomus notatus & right upper molar \\
\hline & & MPM-PV 20707 & Pliolagostomus notatus & right upper molar \\
\hline & & MPM-PV 20708 & Spaniomys $s p$. & right lower molar (broken) \\
\hline & & MPM-PV 20709 & Prolagostomus $s p$. & left lower molar (broken) \\
\hline & & MPM-PV 20710 & Neoreomys sp. & broken tooth \\
\hline & & MPM-PV 20711 & Eocardia $s p$. & broken tooth \\
\hline & & MPM-PV 20712 & Prolagostomus $s p$. & right lower molar \\
\hline & & MPM-PV 20713 & Perimys $s p$. & upper molar \\
\hline & & MPM-PV 20714 & Perimys onustus & P4 and small left maxillary with M1 \\
\hline & & MPM-PV 20715 & Prolagostomus $s p$ & left mandibular fragment with p4-m3 \\
\hline & & MPM-PV 20716 & Prolagostomus $s p$. & right mandibular fragment with $p 4$ \\
\hline & & MPM-PV 20717 & Eocardia/Schistomys & right maxillary fragment with $M 1-M 2$ \\
\hline & & MPM-PV 20718 & Prolagostomus $s p$. & right maxilla with M1-M3(broken) \\
\hline & & MPM-PV 15088 & Acarechimys minutus & left maxillary fragment with DP4-M3 \\
\hline & & MPM-PV 20719 & Spaniomys $s p$. & left mandibular fragment with $m 1$ \\
\hline & & MPM-PV 20720 & Spaniomys sp. & left lower molar \\
\hline & & MPM-PV 20721 & Eocardia $s p$. & isolated tooth \\
\hline & & MPM-PV 20722 & Prolagostomus $s p$. & right lower molar \\
\hline & & MPM-PV 20723 & Sciamys principalis & left mandible with $p 4-m 3$ \\
\hline & & MPM-PV 20724 & cf. Scleromys & right $p 4$ \\
\hline & & MPM-PV 20725 & Steiromys? & left dp4 \\
\hline & & MPM-PV 20726 & Prolagostomus $s p$. & left mandibular fragment with m1-m3 \\
\hline & & MPM-PV 20727 & Stichomys/ Adelphomys & left DP4-M1 \\
\hline & & MPM-PV 20728 & Prolagostomus $s p$. & right upper molar \\
\hline & & MPM-PV 20729 & Prolagostomus $s p$. & left $p 4$ \\
\hline & & MPM-PV 20730 & Pliolagostomus notatus & left upper molar \\
\hline & & MPM-PV 20731 & Pliolagostomus notatus & left $M 3$ \\
\hline & & MPM-PV 20732 & Spaniomys sp. & left maxillary fragment with DP4 \\
\hline & & MPM-PV 20733 & Prolagostomus $s p$. & right lower molar \\
\hline & & MPM-PV 20734 & Stichomys? & left $d p 4$ \\
\hline & & MPM-PV 20735 & Stichomys/ Adelphomys & right upper molar \\
\hline & & MPM-PV 20736 & Prolagostomus $s p$. & 2 broken teeth \\
\hline & & MPM-PV 20737 & Prolagostomus/Pliolagostomus & right upper molar \\
\hline
\end{tabular}


APPENDIX 1 - Continued

\begin{tabular}{|c|c|c|c|c|}
\hline Locality & Estancia & Collection number & Systematic taxonomy & Material \\
\hline & & MPM-PV 20738 & Schistomys erro & $\begin{array}{l}\text { right maxilla with P4-M1 and M2-M3 and left } \\
\text { maxilla with M1-M2 }\end{array}$ \\
\hline & & MPM-PV 20739 & Spaniomys sp. & edentulous left mandible \\
\hline & & MPM-PV 20740 & Sciamys principalis & left mandibular fragment with dp4-m1 \\
\hline & & MPM-PV 20741 & Sciamys principalis & right maxillary fragment with P4-M3 \\
\hline & & MPM-PV 20742 & Sciamys principalis & left mandibular fragment with $p 4-m 3$ \\
\hline & & MPM-PV 17436 & Acarechimys minutus & right mandibular fragment with $d p 4$ \\
\hline & & MPM-PV 20743 & Sciamys $s p$. & right maxillary fragment with P4-M1 \\
\hline & & MPM-PV 20744 & Spaniomys sp. & right maxillary fragment with $\mathrm{M} 2$ \\
\hline & & MPM-PV 20745 & Spaniomys sp. & right M1 or M2 (broken) \\
\hline & & MPM-PV 17439 & Acarechimys gracilis & left mandibular fragment with molar \\
\hline & & MPM-PV 17437 & Acarechimys minutus & left dp4 \\
\hline & & MPM-PV 20746 & Spaniomys sp. & left DP4 \\
\hline & & MPM-PV 20747 & Octodontoidea? & left lower molar \\
\hline & & MPM-PV 20748 & Schistomys erro? & left M3 \\
\hline & & MPM-PV 20749 & Neoreomys australis & right $m 1$ or $m 2$ \\
\hline & & MPM-PV 20750 & Prolagostomus sp. & left mandibular fragment with $m 1-m 2$ \\
\hline & & MPM-PV 20751 & Perimys onustus & left upper molar \\
\hline & & MPM-PV 20752 & Prolagostomus $s p$. & left $p 4$ \\
\hline & & MPM-PV 20753 & Eocardia $s p$. & left lower molar \\
\hline & & MPM-PV 20754 & Eocardia $s p$. & right lower molar (broken) \\
\hline & & MPM-PV 20755 & Pliolagostomus notatus & isolated molar \\
\hline & & MPM-PV 20756 & Pliolagostomus notatus & right lower molar \\
\hline & & MPM-PV 20757 & Pliolagostomus notatus & right lower molar \\
\hline & & MPM-PV 20758 & Pliolagostomus notatus & lower molar \\
\hline & & MPM-PV 20759 & Pliolagostomus notatus & isolated molar \\
\hline & & MPM-PV 20760 & Octodontoidea & right mandibular fragment with incisor \\
\hline & & MPM-PV 20761 & Stichomys/ Adelphomys & right maxillary fragment with DP4(broken)-M2 \\
\hline & & MPM-PV 20762 & Sciamys sp. & right mandible with $m 1-m 2$ \\
\hline & & MPM-PV 20763 & Neoreomys sp. & right upper molar (broken) \\
\hline & & MPM-PV 20764 & Caviomorpha? & proximal ulna fragment? \\
\hline & & MPM-PV 20765 & Neoreomys australis & right lower molar \\
\hline & & MPM-PV 20766 & Spaniomys sp. & left mandibular fragment with $m 1-m 2$ \\
\hline & & MPM-PV 20767 & Spaniomys sp. & right lower molar \\
\hline & & MPM-PV 20768 & Prolagostomus sp. & left M3 \\
\hline & & MPM-PV 20769 & Spaniomys $s p$. & left maxillary fragment with DP4-M1 \\
\hline \multirow{3}{*}{$\begin{array}{l}\text { Yaten } \\
\text { Huageno } \\
(Y H)\end{array}$} & \multirow{3}{*}{$\begin{array}{l}\text { Estancia } \\
\text { El Refugio (EER) }\end{array}$} & MPM-PV 20770 & Spaniomys sp. & left mandibular fragment with $m 1$ \\
\hline & & MPM-PV 20771 & Stichomys regularis & right maxillary fragment with DP4-M1 \\
\hline & & MPM-PV 20772 & Neoreomys australis & left upper molar \\
\hline
\end{tabular}

